\title{
Marine Drugs Regulating Apoptosis Induced by Tumor Necrosis Factor-Related Apoptosis-Inducing Ligand (TRAIL)
}

\author{
Mohammed I. Y. EImallah ${ }^{1,2}$ and Olivier Micheau ${ }^{2,3, *}$ \\ 1 Department of Chemistry, Faculty of Science, Helwan University, Ain Helwan, Cairo 11790, \\ Egypt; E-Mail: mohamed_almallah@science.helwan.edu.eg \\ 2 Institut National de la Santé et de la Recherche Médicale, UMR866, Dijon F-21079, France \\ 3 Unité de Formation et de Recherche, Science de Santé, Dijon F-21079, France \\ * Author to whom correspondence should be addressed; E-Mail: olivier.micheau@inserm.fr; \\ Tel.: +33-380-393-468; Fax: +33-380-393-434.
}

Academic Editor: Keith Glaser

Received: 21 September 2015 / Accepted: 9 November 2015 / Published: 13 November 2015

\begin{abstract}
Marine biomass diversity is a tremendous source of potential anticancer compounds. Several natural marine products have been described to restore tumor cell sensitivity to TNF-related apoptosis inducing ligand (TRAIL)-induced cell death. TRAIL is involved during tumor immune surveillance. Its selectivity for cancer cells has attracted much attention in oncology. This review aims at discussing the main mechanisms by which TRAIL signaling is regulated and presenting how marine bioactive compounds have been found, so far, to overcome TRAIL resistance in tumor cells.
\end{abstract}

Keywords: TNF; TRAIL; Apoptosis; resistance; cancer; marine drugs; alkaloids; carotenoids; sesquiterpenes; macrolactones

\section{Introduction}

Hallmark features of cancer include, among others, genetic mutations that regulate normal cell homeostasis. Mutations of tumor suppressor genes and oncogenes lead to alterations of cell proliferation and cell death pathways, contributing to cancer progression and resistance to treatments [1,2]. Proteins encoded by these master genes play a central role in the occurrence, development, and stability of an organism [2], particularly during embryonic development and immune surveillance [3]. Apoptosis is a physiological cell death process characterized by chromosomal DNA fragmentation, 
nuclear disintegration, cell shrinkage, translocation of the phosphatidyl serine moiety to the outer membrane leaflet, and membrane blebbing [4]. Impairment or resistance to apoptosis leads to various diseases, including autoimmune diseases, degenerative disorders, and cancer. The molecular mechanisms by which tumor cells gain resistance to apoptosis mainly include (1) a dysregulation of the mitochondrial pathway; (2) the inactivation or the loss of caspases; and/or (3) a deficiency of death signals through the transmembrane death receptors of the TNF superfamily [5-7]. Overcoming resistance to apoptosis is probably the most important challenge in oncology. This review focuses on TRAIL signaling regulation by marine bioactive compounds, as it is anticipated that these combinations may be valuable in cancer therapy.

\section{TRAIL-Signaling and Regulation in Cancer}

\subsection{Activation of Apoptosis by TRAIL}

TRAIL agonist receptors contain an intracellular death domain (DD) that enables the assembly of the death-inducing signaling complex (DISC), leading eventually to apoptosis (Figure 1). Like most death ligands of the TNF superfamily, TRAIL binding to its cognate agonistic receptors triggers their aggregation, and with the exception of TNF-R1 [8], subsequent recruitment of the adaptor protein FADD (Fas Associated Death Domain) at the membrane level [9], through DD homotypic interactions (Figure 1). Once associated with TRAIL agonist receptors, FADD in turn enables the recruitment of the initiators caspases, namely caspase- 8 and/or caspase-10, through its death effector domain (DED). DED-containing proteins, like proteins harboring DD's, are able to interact with themselves and one another [10]. They are required for DISC assembly. Although the precise stochiometry of this complex remains partially unsolved, two independent studies have recently demonstrated that caspase- 8 recruitment could lead to the formation of caspase- 8 chains, representing up to nine-fold more caspase- 8 than FADD [11,12]. Recruitment of these initiator caspases in a defined subcellular compartment within this scaffold is sufficient to induce their activation. An induced-proximity model was originally proposed in the late 1990's to explain caspase- 8 processing and activation following stimulation with another ligand of the TNF family, namely CD95L/Fas ligand [13,14]. Within the DISC, self-processing of caspase- 8 or caspase-10, leads to the release of their active fragments to the cytosol. These fragments are composed of a large and a small catalytic subunit. Their assembly is sufficient to induce the cleavage and the activation of executioner caspases, including caspase- 3 or caspase-7, leading to apoptosis (Figure 1).

The contribution of caspase- 8 in triggering apoptosis upon engagement of the death receptors is largely accepted in the community. However, the ability of caspase-10 to substitute for a lack of caspase- 8 remains a matter of debate [15], despite the fact that this initiator caspase was shown to restore both TRAIL- and Fas ligand-induced apoptosis in caspase-8-deficient neuroblastoma [16] and the caspase-8-deficient Jurkat T lymphoma derivative cell line [17]. Irrespective of whether caspase-10 is able to substitute, or not, for caspase-8, the outcome of their activation, upon TRAIL stimulation, heavily relies on the cell type which, itself, is dependent on the strength of activation of these initiator caspases. In so-called type I cells, caspase-8/-10 activation is sufficient to trigger apoptosis directly through executioner caspases, while activation of executioner caspases and apoptosis in type II cells 
require mitochondria (Figure 1). Activation of this intrinsic pathway is mediated through the cleavage of Bid, a caspase-8 and -10 substrate, belonging to the BH3-only Bcl-2 family [18,19]. Once cleaved, truncated $\mathrm{Bid}$ (tBid) translocates to mitochondria and induces mitochondrial outer membrane permeabilization, through oligomerization of Bak and/or Bax, allowing the release of cytochrome $\mathrm{c}$ to the cytosol [20,21] and formation of the apoptosome [22]. This soluble multimeric complex scaffold, composed of the multimeric adaptor protein APAF-1, cytochrome c, dATP, and caspase-9 enables the activation of the initiator caspase [23]. Once activated, caspase- 9 cleaves and activates executioner caspases.

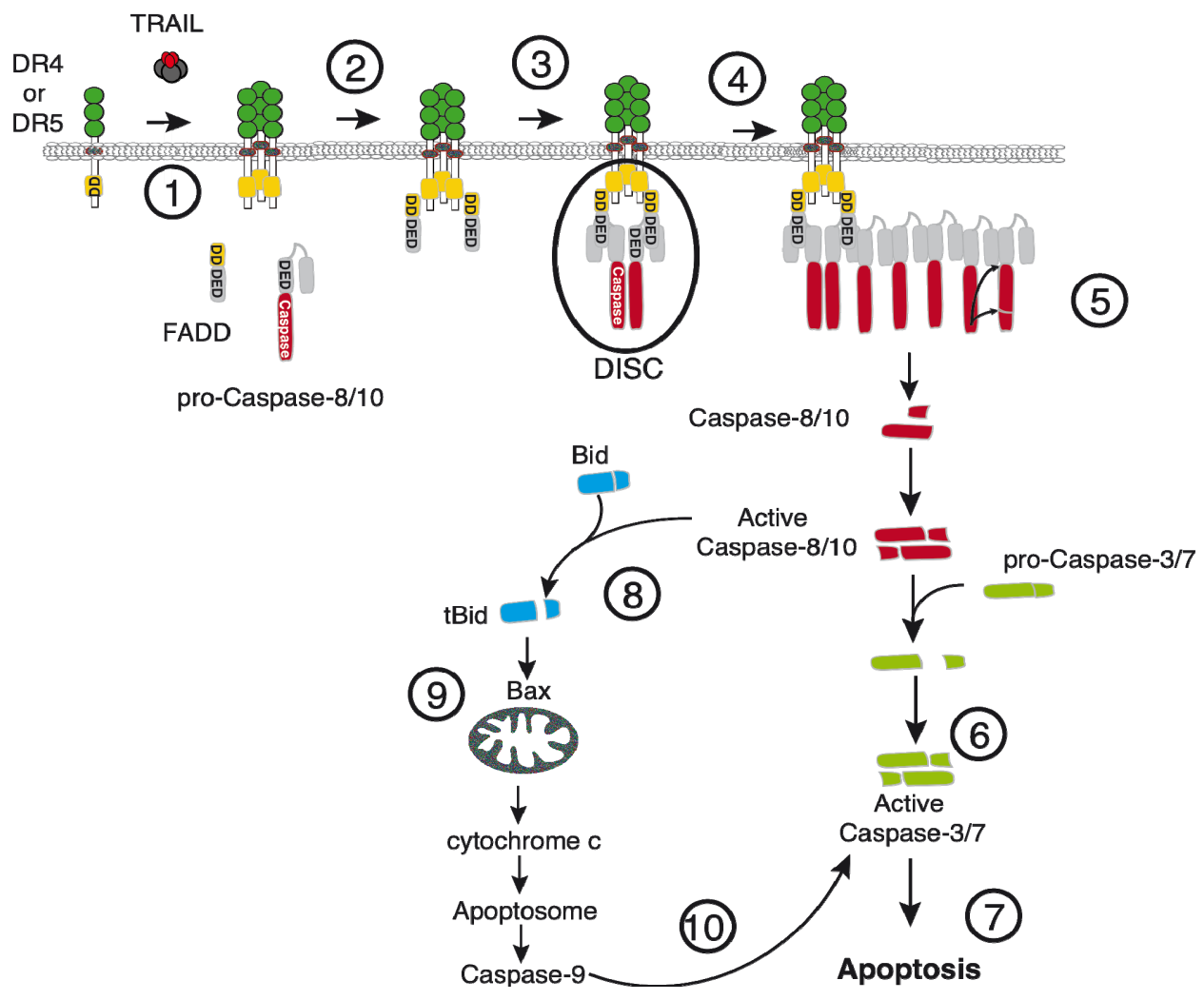

Figure 1. Schematic representation of apoptosis induced by TRAIL. Binding of TRAIL to its agonistic receptors (DR4 and/or DR5) leads to their oligomerization (1), and the subsequent recruitment of the cytosolic adapter protein FADD through DD homotypic interactions (2). FADD, in turn, enables recruitment of the initial pro-caspase-8/-10 through DED interactions leading to the formation of the so-called DISC (death-inducing signaling complex (3)). Within the DISC, chains of caspase-8/-10 are assembled (4), allowing self-processing of caspase-8/10 and release of their active fragments to the cytosol (5), where they activate, by proteolytic cleavage, effector caspases (6) to execute the apoptotic program (7). Amplification of the signal through the intrinsic pathway is sometimes required when caspase- 8 is not sufficiently activated. In this scenario activation of mitochondria is induced by caspase-8/-10 through cleavage of the BH3-only Bcl-2 family protein $\mathrm{Bid}(8)$, whose truncated version (tBid) is able to translocate to mitochondria and induce a change of their outer membrane permeability, through Bak and Bax interactions (9), allowing cytochome c release, activation of caspase-9, another initiator caspase able to activate the executioner caspase-3/-7 (10). 


\subsection{Negative Regulators of TRAIL}

Efficient activation of initiator caspases, upon TRAIL stimulation, is tightly dependent on the quality of the DISC, determining the strength of activation of the initiator caspases [24]. Irrespective of whether the apoptotic signal is transduced by DR4 or DR5, through homomultimers or heteromultimers, and provided that enough receptors, FADD, or initiator caspases are expressed by a given cell line, selective inhibition of this pro-apoptotic signaling pathway can result from concomitant expression of any of the three antagonistic receptors, namely DcR1 (TRAIL-R3) [25,26], DcR2 (TRAIL-R4) [27,28], or a soluble receptor called OPG (osteoprotegerin) [29] (Figure 2). Amongst these antagonist receptors, OPG is probably the weakest inhibitor, owing to its lower affinity for TRAIL [30]. OPG exhibits much higher affinity for RANKL and its physiological function has, so far, mainly been ascribed to osteoclasts development and activation [31]. Nevertheless this soluble receptor was shown to be able to compete, to some extent, with DR4 or DR5 for TRAIL binding [29,32]. DcR1 and DcR2, on the other hand, owing to their higher affinity for TRAIL [26,30], have been studied more extensively to assess their ability to inhibit TRAIL pro-apoptotic signaling. These receptors are both devoid of functional DD and display differential inhibitory properties. While DcR1, whose c-terminus harbors a glycosylphosphatidyl-inositol (GPI) motif, is localized in lipid rafts, DR4, DR5, and DcR2 are mostly found in non-lipid rafts portions of the plasma membrane, even when engaged within the TRAIL DISC [33]. DcR1 is unable to form heteromultimers with DR4 or DR5 upon TRAIL stimulation. Therefore, like OPG, DcR1 appears to inhibit TRAIL-induced apoptosis in a competitive manner by titrating its cognate ligand [33]. DcR2, on the other hand, is co-recruited with DR4 [34] and DR5 [33] within the TRAIL DISC, in non-lipid rafts fractions (Figure 2). Recruitment of DcR2 within the TRAIL DISC leads to the formation of a heteromultimeric complex, whose ability to trigger initiator caspase activation is reduced, as compared to DR4 and/or DR5 homomultimeric or heteromultimeric complexes [33,34]. Since DcR2 is devoid of functional DD, it has been proposed that its recruitment within the TRAIL complex may impede caspase- 8 activation by mere steric hindrance [35]. More recently, DcR1 and DcR2 were found to be able to act, in addition, in trans by titrating TRAIL on stroma cells within the tumor microenvironnement [36].

In addition to these non-functional receptors, or the lack of expression of the agonistic receptors DR4 or DR5 [37-39], resistance to TRAIL-induced cell death can arise in tumor cells owing to a large variety of events, including a loss of caspase-8 expression [40] or the overexpression of c-FLIP [41,42] (Figure 2), the main inhibitor of caspase-8 [43]. Viral and cellular dominant negative homologues of caspase- 8 and caspase-10, coined v-FLIPs and c-FLIPs, respectively, have been discovered in the late 1990s [43,44]. Like caspase- 8 and caspase-10 these inhibitors harbor two DEDs and as such, can be recruited within the TRAIL DISC (For recent reviews see, [41,45]). The long form of c-FLIP contains a caspase-like domain but this domain is devoid of caspase catalytic activity [43]. Owing to their ability to be co-recruited with caspase- 8 within the DISC and to inhibit caspase- 8 chain formation [46], self-processing and activation [47], c-FLIP isoforms are mostly associated with inhibition of apoptosis induced by ligands of the TNF family (Figure 3). It should be noted, however, that the long isoform of c-FLIP is also able to activate caspase- 8 within the DISC $[48,49]$ by mere dimerization in the absence of proteolytic activity [50]. However, activation of caspase- 8 by this long isoform of c-FLIP does not lead to caspase- 8 release to the cytosol and, thus, caspase- 3 activation. Cells expressing high levels of 
this isoform are, thus, protected from apoptosis induced by ligands of the TNF family. Furthermore, increasing evidence suggests that c-FLIP isoforms can also inhibit other cell death machineries, including apoptosis induced by TLR3 [51], unfolded protein response [52], or chemotherapy [53-55].

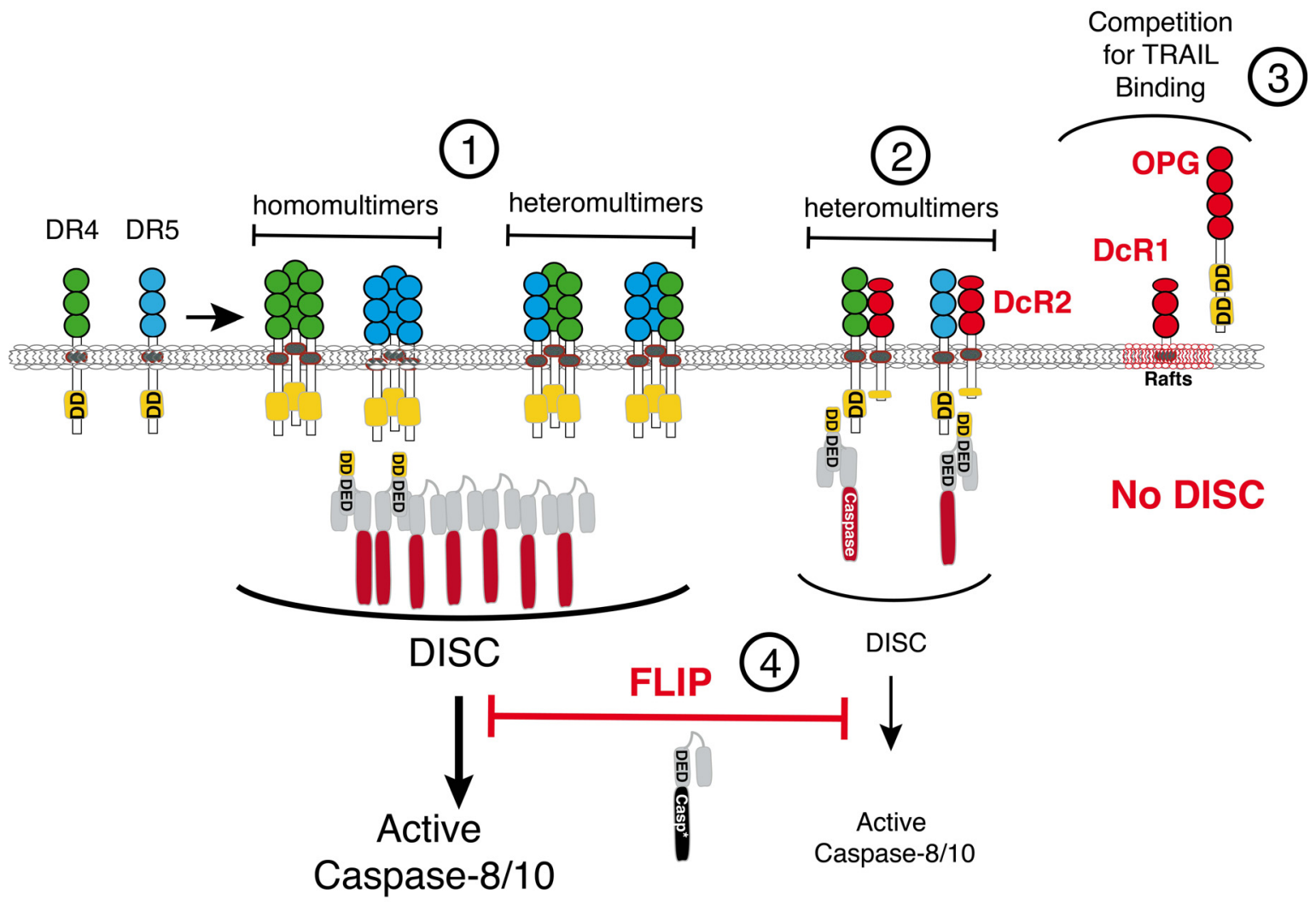

Figure 2. Schematic representation of TRAIL pro-apoptotic proximal signaling regulation. Apoptosis induced by TRAIL is initiated through homo/or hetero-oligomerization of DR4 and/or DR5 and subsequent chain assembly of initiator caspases (1). Proximal activation of caspase- 8 by these receptors can be inhibited by TRAIL antagonistic receptors DcR2 (2), DcR1, and OPG (3), as well as by the cellular caspase-8 inhibitor, c-FLIP (4) (see text for explanations).

Further downstream, in type II cells, since apoptosis requires the amplification of the caspase cascade through mitochondria ([56], see also Figure 1), resistance can also be induced by a deficiency in Bax [57] or the overexpression of B-cell lymphoma 2 (Bcl-2) anti-apoptotic protein family members, including Bcl-2 itself, Mcl-1, or Bc-xL (Figure 3) [58-60]. Last, but not least, irrespective of whether the tumor cell requires amplification of the signal through mitochondria or not, apoptosis induced by TRAIL can also be restrained by the overexpression of XIAP or survivin [61-63] (Figure 3).

Owing to the large number of events that can affect TRAIL's efficacy, combined treatments associating cytotoxic drugs and TRAIL or TRAIL variants have emerged to restore TRAIL sensitivity in resistant tumor cells [24,64-73]. Interestingly, conventional or non-conventional chemotherapeutic drugs can overcome TRAIL resistance through (1) restoration of TRAIL agonist receptor expression [74-80]; (2) restoration of caspase-8 recruitment and activation at the DISC level [24,81,82], or inhibition of c-FLIP expression [66,83-89]; (3) inhibition of Bcl-2, Bcl-xL, Mcl-1, or up-regulation of Bax 
expression [60,65,90,91]; and/or (4) down-regulation of survivin and/or XIAP expression [61,65,92-94] (Figure 3).

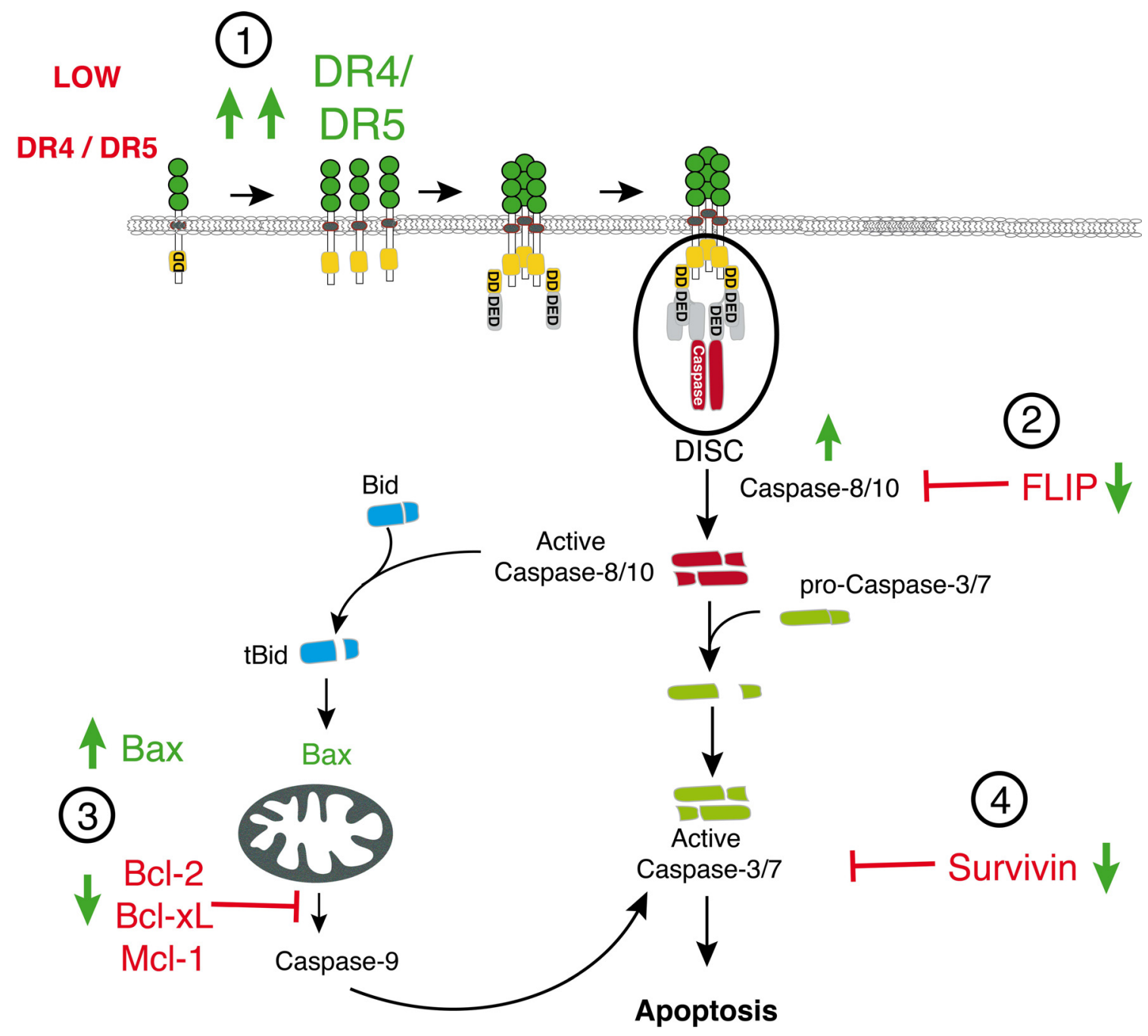

Figure 3. Schematic representation of the main TRAIL signaling or regulator components targeted by conventional chemotherapies to restore TRAIL-induced apoptosis. Restoration of apoptosis induced by TRAIL in resistant tumor cells can be induced through restoration of DR4 and/or DR5 (1), caspase-8/10 (2), or Bax expression (3), or down-regulation of anti-apoptotic factors such as c-FLIP (2), Bcl-2 family proteins (Bcl-2, Mcl-1, or Bcl-xL (3)), and/or survivin or XIAP (4). 


\subsection{Survival Signaling Pathways Regulating TRAIL-Induced Apoptosis}

Signaling pathways such as mitogen-activated protein kinase (MAPK) and nuclear factor kappaB $(\mathrm{NF}-\mathrm{kB})$ were also reported to have a significant impact on the resistance or sensitivity of cancer cells to TRAIL [95]. TRAIL, itself, has been described to be able to induce their activation [96-102]. While it has been proposed that activation MAPK signaling by TRAIL involved the formation of a soluble secondary complex [103], the molecular events leading to their activation remain poorly understood.

In higher organisms, MAP kinases are a highly conserved family of protein kinases mainly consisting of three distinct members of MAPK, extracellular signal-regulated kinases (ERKs), c-jun N-terminal protein kinases (JNKs), and p38 MAP kinases [104]. MAPK-induced survival signaling cascades are impeded in several cellular events like cell differentiation, proliferation, inflammatory response, stress response, and cell death. These cascades are initiated by extracellular stimuli including, cytokines, growth factors, hormones, and environmental stressors, which transmit via transmembrane receptors into the intracellular compartment $[105,106]$.

ERK1/2 activation was first associated with protection of transformed cells to TRAIL-induced apoptosis [99,107,108], but increasing evidence suggest that ERK activation could induce, through the transcription factor $\mathrm{CHOP} / \mathrm{GADD} 153$, the up-regulation of DR5, as well as, to a lesser extent, that of DR4, allowing restoration of TRAIL-induced cell death in resistant cells [109-116]. JNK is involved in both cell proliferation and apoptosis, whereas p38 kinases are considered as cytokines regulating enzymes that are expressed in response to different stressful environmental conditions. The JNK pathway is regulated by the mitogen-activated protein kinase kinase (MKK) family proteins'-induced phosphorylation and is induced by TRAIL through the receptor-interacting protein kinase 1 (RIPK1) and TNF receptor-associated factor 2 (TRAF2) [117-119]. The mechanism of TRAIL-induced apoptosis linked to the activation of $\mathrm{JNK}$ and p38 kinase has been reported by several studies $[73,91,120]$.

Similar to ERK, activation of JNK or p38, depending on the tumor cell line and trigger, can act in a transcriptional-dependent or independent manner to induce the regulation of TRAIL agonist receptors, c-FLIP or Bcl-2 family proteins to restore or inhibit apoptosis-induced by TRAIL [91,109,121-133].

The phosphoinositide-3-kinase-protein kinase B/Akt (PI3K-PKB/Akt) is a highly conserved, and tightly controlled, signaling pathway [134]. Its activation can be triggered by a wide range of stimuli, including tyrosine kinase receptors, integrins, B and T cell receptors, or G-protein-coupled receptors [135]. Activation of this survival pathway leads to the phosphorylation and activation of Akt by PI3K. Active Akt, in turn, phosphorylates a number of substrates [136], leading to transcriptional up-regulation or phosphorylation-dependent stabilization of survival genes such as c-FLIP, Bcl-2, Mcl-1, or XIAP, and ultimately to TRAIL resistance [137-144].

$\mathrm{NF}-\kappa \mathrm{B}$ is a nuclear transcription factor, expressed in response to a wide variety of stimuli such as inflammatory response, immune modulation, cell proliferation, and apoptosis. It consists of five subunits

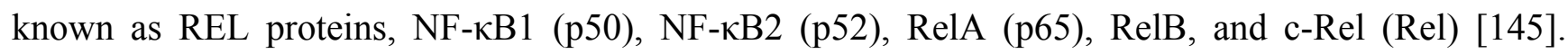
Normally, NF- $\kappa \mathrm{B}$ exists in the cytoplasm in an inactive form by forming a heterodimer with its regulatory protein inhibitor IKB. Phosphorylation of IкB by IкB kinase (IKK) complex (IKK $\alpha$ and $\mathrm{IKK} \beta$ ) and its regulatory subunit NF- $\mathrm{KB}$ essential modulator (NEMO)/inhibitor of nuclear factor kappa-B kinase subunit gamma (IKK $\gamma$ ) releases NF- $\mathrm{kB}$ stimulating its translocation into the nucleus. 
Activation of NF- $\mathrm{KB}$ occurs via the molecular assembly of its subunits into homodimeric and heterodimeric forms that interact with the promoter of target genes [146].

Two independent signaling pathways were reported through which NF- $\kappa$ B signal transduction is activated $[147,148]$. The first pathway, the canonical pathway, is initiated by various stimuli, including tumor necrosis factor $\alpha$ (TNF $\alpha$ ), interleukins-1 $\beta$ (IL-1 $\beta$ ), interleukin-6 (IL-6), and members of toll-like receptors (TLRs) family. Binding of these ligands to their cognate receptors leads to the activation of the IKK complex and its regulatory subunit NEMO/IKK $\gamma$, inducing phosphorylation of IKB $\alpha$ on Ser32 and Ser36 residues [149,150]. Phosphorylation of $\mathrm{I} \kappa \mathrm{B} \alpha$ on these serine residues enables the binding of an E3 ubiquitin protein ligase called beta-transducin repeat containing protein $(\beta-\operatorname{TrCP})$, ubiquitination and proteosomal degradation of I $\kappa \mathrm{B} \alpha$, leading to the release of NF- $\kappa \mathrm{B}$ and to its nuclear translocation [151]. The non-canonical pathway is mediated by a group of non-inflammatory signals such as B-cell activation factor (BAFF)/CD40 essential for the survival of B-cell, the lymph node development factor lymphotoxin $\beta$ (LT $\beta$ ), and the receptor activator of NF- $\kappa B$ ligand (RANKL), which plays a central role in the differentiation of the osteoclasts [152]. Initiation of this pathway requires NF- $\kappa B$-inducing kinase (NIK) but not the $\gamma$ subunit of IKK, NEMO [153]. The p100 subunit of NF- $\kappa \mathrm{B}$ linked to RelB is then phosphorylated by the activated IKK $\alpha$ and the phosphorylated p100-RelB complex is finally cleaved and processed, leading to the formation of the p52-RelB complex [154]. Activation of NF- $\mathrm{KB}$ canonical pathway has mostly been demonstrated to inhibit TRAIL-induced apoptosis through up-regulation of c-FLIP [96,98,119,155-165], but a recent study demonstrated that its activation in glioblastoma cells could contribute to Fas/CD95- and TRAIL-induced apoptosis [166].

\section{Marine-Derived Compounds Regulating Apoptotic Signal Transduction Induced by TRAIL}

Restoration or enhancement of apoptosis induced by TRAIL in resistant cancer is a prerequisite for the use of TRAIL in the clinic [167,168]. Exploration of natural products derived from terrestrial plants and marine fauna or flora pharmacopeia is, thus, likely to provide potent and selective TRAIL-sensitizing compounds [169-172]. The marine environment is enriched with a wide variety of living organisms, including bacteria, actinobacteria, sponges, fungi, microalgae, soft corals, seaweeds and flowering plants, such as mangroves, which have been reported as unexplored source for the discovery of potential anti-cancer compounds [173], as well as anti-bacterial, anti-fungal, antioxidants, or immunomodulatory activities [173-175]. This biomass diversity is considered as an unlimited source of structurally novel bioactive compounds, whose structural novelties, as well as variation in chemical features, confer to these organisms unique properties allowing them to survive in extreme marine environmental conditions, such as high salinity, temperature, or pressure [176-178]. Several natural marine products have been reported for their potent TRAIL-sensitizing effect in various TRAIL-resistant cancer cell lines (Table 1 and Figure 4) [171,179]. 


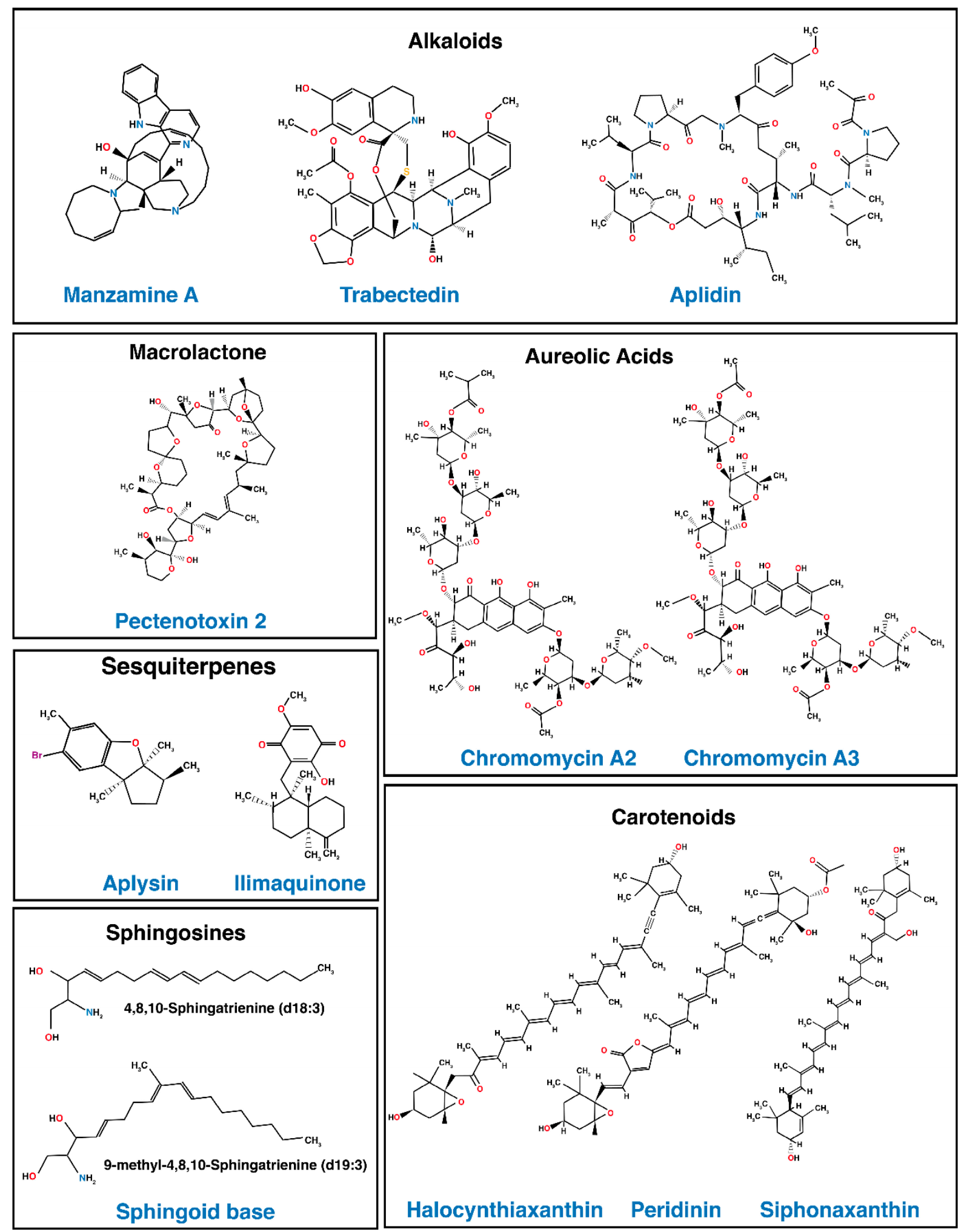

Figure 4. Selected marine-derived natural products with potent TRAIL-resistance overcoming activity. 
Table 1. Marine derived compounds with TRAIL-overcoming resistance activity and/or able to regulate TRAIL signaling components or inhibitors.

\begin{tabular}{|c|c|c|c|c|c|}
\hline $\begin{array}{c}\text { Chemical } \\
\text { Class }\end{array}$ & Drug & Marine Source & $\begin{array}{c}\text { Target } \\
\text { Cell Line }\end{array}$ & Effects & $\begin{array}{c}\text { Restores or } \\
\text { Enhances } \\
\text { TRAIL-Induced } \\
\text { Apoptosis } \\
\end{array}$ \\
\hline \multirow{3}{*}{ Alkaloid } & Manzamine A & Marine Sponge & AsPC-1 [180] & - Inhibition of GSK $3 \beta$ and NF-кB & Yes \\
\hline & Trabectedin & Marine Tunicate & $\begin{array}{c}\text { MCF-7 \& } \\
\text { MDA-MB-453 } \\
{[181]}\end{array}$ & $\begin{array}{l}\text { - Up-regulation of DR4, DR5, FADD, } \\
\text { Bax, Bad } \\
\text { - Down-regulation of Bcl-2, Bcl-xL, } \\
\text { XIAP and survivin }\end{array}$ & Yes \\
\hline & Aplidin & Marine Tunicate & $\begin{array}{c}\text { Multiple } \\
\text { Myeloma } \\
\text { cell lines and } \\
\text { tumors [179] }\end{array}$ & $\begin{array}{l}\text { - Activation of p38 and JNK MAPK } \\
\text { - Down regulation of Mcl-1, Survivin } \\
\text { - Up-regulation of TRAIL }\end{array}$ & Not Tested \\
\hline Aureolic acid & $\begin{array}{l}\text { Chromomycins A2 } \\
\text { Chromomycins A3 }\end{array}$ & Actinomycetes & AGS [182] & - Inhibition of wnt/ $\beta$-catenin & Yes \\
\hline \multirow{3}{*}{ Carotenoids } & Halocynthiaxanthin & Oysters and Sea Squirts & DLD-1 [183] & - Up-regulation of DR5 & Yes \\
\hline & Peridinin & Squirt Botrylloides & DLD-1 [183] & - Up-regulation of DR5 & Yes \\
\hline & Siphonaxanthin & Green Algae & HL-60 [184] & $\begin{array}{l}\text { - Up-regulation of DR5 } \\
\text { - Down-regulation of Bcl-2 }\end{array}$ & Not Tested \\
\hline Macroloactones & Pectenotoxin-2 & Marine Sponge & $\begin{array}{c}\text { Hep3B \& } \\
\text { HepG2 [185] }\end{array}$ & $\begin{array}{l}\text { - Up-regulation of DR4, DR5, and Bax. } \\
\text { - Down-regulation of Bcl-2 and } \\
\text { Bcl-xL }\end{array}$ & Not Tested \\
\hline \multirow{2}{*}{ Sesquiterpene } & Aplysin & Seaweed & $\mathrm{MCF}-7[122]$ & $\begin{array}{l}\text { - Inhibition of p38 MAPK/ } \\
\text { survivin pathway. }\end{array}$ & Yes \\
\hline & Ilimaquinone & Marine Sponge & $\begin{array}{l}\text { HCT116 \& } \\
\text { HT29 [126] }\end{array}$ & $\begin{array}{l}\text { - Up-regulation of DR4 and DR5 } \\
\text { through ERK/p38 and CHOP }\end{array}$ & Yes \\
\hline Sphingosine & Sphingoid bases & Sea Cucumber & HepG2 [186] & $\begin{array}{l}\text { - Up-regulation DR5 and Bax, } \\
\text { - Down-regulation of Akt/(PKB). }\end{array}$ & Not Tested \\
\hline
\end{tabular}

\subsection{Marine-Derived Compounds Enhancing Apoptotic Signal Transduction Induced by TRAIL}

Manzamine A is an alkaloid isolated from marine sponge Haliclona sp. displaying TRAIL-sensitizing activities. Manzamine A was suggested to restore TRAIL-induced apoptotic cell death in the TRAIL-resistance pancreatic AsPC-1 cell line via inhibition of glycogen synthase kinase-3 $\beta$ (GSK $3 \beta$ ) and subsequent inhibition of the survival factor NF-kB [180].

The marine-derived compounds chromomycins $\mathrm{A} 2$ and $\mathrm{A} 3$, extracted from actinomycete, are members of the aureolic acid family. These compounds have been shown to enhance human gastric adenocarcinoma AGS cell line sensitivity to TRAIL-induced cell death. The molecular mechanism involved remains unknown, but the authors suggested that sensitization could be correlated with chromomycin A2 and A3's ability to inhibit wnt/ $\beta$-catenin signaling [182].

Marine derived carotenoids have also been demonstrated to increase TRAIL sensitivity. Halocynthiaxanthin and peridinin, two carotenoids extracted from oysters and sea squirts were shown 
to display significant TRAIL sensitizing properties in the resistance colon cancer DLD-1 cell line [183]. Both carotenoids induced the up-regulation of DR5 and enhanced apoptosis induced by TRAIL.

Aplysin is a brominated sesquiterpene marine natural product isolated from the seaweed Laurencia tristicha. It was found to enhance apoptosis-induced by TRAIL in two human TRAIL resistant tumors, namely the MCF-7 breast cancer and A549 non-small lung cancer cell lines [122]. Restoration of TRAIL anti-tumor activity in these cells was proposed to occur through the activation of p38 MAPK and inhibition of survivin. Ilimaquinone was originally isolated from the Hawaiian sponge Hippiospongia metachromia. This sesquiterpene sensitizes human colon cancer cells to TRAIL through a CHOP-dependent regulation of DR5 [126]. In addition to DR5, up-regulation of DR4 and simultaneous down-regulation of Bcl-2 and Bcl-xL were also described in this study. Importantly, it was found that ilimaquinone-mediated up-regulation of both DR4 and DR5 required activation of ERK and p38 MAPK signaling as well as ROS production.

\subsection{Marine-Derived Compounds Regulating TRAIL Signaling Components}

Other marine-derived compounds have been described to exhibit antitumor properties associated with abilities to induce or repress expression levels of components of TRAIL death signal machinery. Likewise aplidin and trabectedin are two alkaloids from marine tunicate. Aplidin was demonstrated to induce the activation of $\mathrm{p} 38$ and JNK, to inhibit expression levels of Mcl-1 and survivin and to induce the expression of TRAIL in multiple myeloma primary tumors and cell lines [179]. In a previous study, aplidin was also found to induce translocation of TNF receptors into lipid rafts, in the leukemic Jurkat cell line, including translocation of DR5 [187]. Trabectedin, on the other hand, was suggested to induce apoptosis in resistant breast cancer cell lines either through the up-regulation of DR4, DR5, and FADD and the down-regulation of XIAP and survivin or through the up-regulation of Bax and Bak and the down-regulation of Bcl-2, Bcl-xL and survivin, in MCF7 and MDA-MB-453, respectively [181]. It should thus be kept in mind that since trabectedin is able to sensitize tumor cells to CD95/Fas-mediated cell death at a nM range [188], although it has not been described so far, this compound is thus also likely to restore apoptosis induced by TRAIL. Aplidin and trabectedin, are extensively assessed in phase II and III clinical trials for their antitumoral properties [189,190]. Of note, trabectedin, also known as Yondelis, has recently been approved by the FDA for patients suffering from advanced soft-tissue sarcomas [191].

In the same vein it is interesting to note that another carotenoid derived from green algae, siphonaxanthin, which exerts a potent cytotoxic effect on the human leukemia HL-60 cell line, was demonstrated to be able to induce the up-regulation of DR5 [184]. Although TRAIL sensitivity was not evaluated in this work, these findings suggest that this class of marine-derived carotenoids may be of interest to restore apoptosis induced by TRAIL (Table 1 and Figure 4).

Other marine derived compounds share the ability to induce the up-regulation of DR5 or to inhibit Bcl-2 anti-apoptotic members. Likewise, pectinotoxin-2 (PTX-2), a marine sponge-derived macroloactone, was shown to induce apoptosis in the human hepatocellular carcinoma Hep3B cell line. In these cells apoptosis correlated with the up-regulation of DR4, DR5 and Bax and the down-regulation of Bcl-2 and Bcl-xL [185]. Last, sphingoid bases extracted from sea cucumber were found to induce apoptosis 
the human hepatocellular carcinoma HepG2 cell line through a mechanism associated with inhibition of AKT phosphorylation and up-regulation of both Bax and DR5 [186].

\section{Conclusions}

Marine-derived compounds found, so far, to regulate directly or indirectly TRAIL-signaling represent only the tip of the iceberg. Through their ability to regulate MAPKs, NF- $\kappa$, ROS production, and ER stress (i.e., GADD153/CHOP), these compounds are able to restore or induce the expression of TRAIL signaling pro-apoptotic partners and to reduce the amount of anti-apoptotic regulators. The extraordinary diversity of chemical structures naturally produced from ocean living organisms is, thus, more than likely to deliver potent molecules allowing the efficient use of TRAIL or TRAIL derivatives in the clinic. Twenty years have passed since the cloning of TRAIL [192]. Rendezvous in a decade or two to find out whether marine-derived compounds meet our expectations.

\section{Acknowledgments}

This work was partly supported by grants from the program "Investissements d'Avenir" with reference ANR-11-LABX-0021-01-LipSTIC Labex, the Conseil Regional de Bourgogne, the INCa (Institut National du Cancer, PLBIO14-007) and European Regional Development FEDER funds.

\section{Conflicts of Interest}

The authors declare no conflict of interest.

\section{References}

1. Hahn, W.C.; Counter, C.M.; Lundberg, A.S.; Beijersbergen, R.L.; Brooks, M.W.; Weinberg, R.A. Creation of human tumour cells with defined genetic elements. Nature 1999, 400, 464-468.

2. Fanidi, A.; Harrington, E.A.; Evan, G.I. Cooperative interaction between c-myc and bcl-2 proto-oncogenes. Nature 1992, 359, 554-556.

3. Cavin, L.G.; Venkatraman, M.; Factor, V.M.; Kaur, S.; Schroeder, I.; Mercurio, F.; Beg, A.A.; Thorgeirsson, S.S.; Arsura, M. Regulation of alpha-fetoprotein by nuclear factor-kappaB protects hepatocytes from tumor necrosis factor-alpha cytotoxicity during fetal liver development and hepatic oncogenesis. Cancer Res. 2004, 64, 7030-7038.

4. Kerr, J.F.; Winterford, C.M.; Harmon, B.V. Apoptosis. Its significance in cancer and cancer therapy. Cancer 1994, 73, 2013-2026.

5. Fulda, S. Exploiting mitochondrial apoptosis for the treatment of cancer. Mitochondrion 2010, 10, 598-603.

6. Olsson, M.; Zhivotovsky, B. Caspases and cancer. Cell Death Differ. 2011, 18, 1441-1419.

7. Walczak, H. Death receptor-ligand systems in cancer, cell death, and inflammation. Cold Spring Harb. Perspect. Biol. 2013, 5, doi:10.1101/cshperspect.a008698.

8. Micheau, O.; Tschopp, J. Induction of TNF receptor I-mediated apoptosis via two sequential signaling complexes. Cell 2003, 114, 181-190. 
9. Bodmer, J.L.; Holler, N.; Reynard, S.; Vinciguerra, P.; Schneider, P.; Juo, P.; Blenis, J.; Tschopp, J. TRAIL receptor-2 signals apoptosis through FADD and caspase-8. Nat. Cell Biol. 2000, 2, 241-243.

10. Riley, J.S.; Malik, A.; Holohan, C.; Longley, D.B. DED or alive: Assembly and regulation of the death effector domain complexes. Cell Death Dis. 2015, 6, e1866.

11. Dickens, L.S.; Boyd, R.S.; Jukes-Jones, R.; Hughes, M.A.; Robinson, G.L.; Fairall, L.; Schwabe, J.W.; Cain, K.; Macfarlane, M. A death effector domain chain DISC model reveals a crucial role for caspase- 8 chain assembly in mediating apoptotic cell death. Mol. Cell 2012, 47, 291-305.

12. Schleich, K.; Warnken, U.; Fricker, N.; Ozturk, S.; Richter, P.; Kammerer, K.; Schnolzer, M.; Krammer, P.H.; Lavrik, I.N. Stoichiometry of the CD95 death-inducing signaling complex: Experimental and modeling evidence for a death effector domain chain model. Mol. Cell 2012, 47, 306-319.

13. Salvesen, G.S.; Dixit, V.M. Caspase activation: The induced-proximity model. Proc. Natl. Acad. Sci. USA 1999, 96, 10964-10967.

14. Muzio, M.; Stockwell, B.R.; Stennicke, H.R.; Salvesen, G.S.; Dixit, V.M. An induced proximity model for caspase-8 activation. J. Biol. Chem. 1998, 273, 2926-2930.

15. Sprick, M.R.; Rieser, E.; Stahl, H.; Grosse-Wilde, A.; Weigand, M.A.; Walczak, H. Caspase-10 is recruited to and activated at the native TRAIL and CD95 death-inducing signalling complexes in a FADD-dependent manner but can not functionally substitute caspase-8. EMBO J. 2002, 21, 4520-4530.

16. Muhlethaler-Mottet, A.; Flahaut, M.; Bourloud, K.B.; Nardou, K.; Coulon, A.; Liberman, J.; Thome, M.; Gross, N. Individual caspase-10 isoforms play distinct and opposing roles in the initiation of death receptor-mediated tumour cell apoptosis. Cell Death Dis. 2011, 2, doi:10.1038/cddis.2011.8.

17. Milhas, D.; Cuvillier, O.; Therville, N.; Clave, P.; Thomsen, M.; Levade, T.; Benoist, H.; Segui, B. Caspase-10 triggers Bid cleavage and caspase cascade activation in FasL-induced apoptosis. J. Biol. Chem. 2005, 280, 19836-19842.

18. Yamada, H.; Tada-Oikawa, S.; Uchida, A.; Kawanishi, S. TRAIL causes cleavage of bid by caspase- 8 and loss of mitochondrial membrane potential resulting in apoptosis in BJAB cells. Biochem. Biophys. Res. Commun. 1999, 265, 130-133.

19. Li, H.; Zhu, H.; Xu, C.J.; Yuan, J. Cleavage of BID by caspase 8 mediates the mitochondrial damage in the Fas pathway of apoptosis. Cell 1998, 94, 491-501.

20. Desagher, S.; Osen-Sand, A.; Nichols, A.; Eskes, R.; Montessuit, S.; Lauper, S.; Maundrell, K.; Antonsson, B.; Martinou, J.C. Bid-induced conformational change of Bax is responsible for mitochondrial cytochrome c release during apoptosis. J. Cell. Biol. 1999, 144, 891-901.

21. Korsmeyer, S.J.; Wei, M.C.; Saito, M.; Weiler, S.; Oh, K.J.; Schlesinger, P.H. Pro-apoptotic cascade activates BID, which oligomerizes BAK or BAX into pores that result in the release of cytochrome c. Cell Death Differ. 2000, 7, 1166-1173.

22. Zou, H.; Li, Y.; Liu, X.; Wang, X. An APAF-1.cytochrome c multimeric complex is a functional apoptosome that activates procaspase-9. J. Biol. Chem. 1999, 274, 11549-11556. 
23. Li, P.; Nijhawan, D.; Budihardjo, I.; Srinivasula, S.M.; Ahmad, M.; Alnemri, E.S.; Wang, X. Cytochrome $\mathrm{c}$ and dATP-dependent formation of Apaf-1/caspase-9 complex initiates an apoptotic protease cascade. Cell 1997, 91, 479-489.

24. Morizot, A.; Merino, D.; Lalaoui, N.; Jacquemin, G.; Granci, V.; Iessi, E.; Lanneau, D.; Bouyer, F.; Solary, E.; Chauffert, B.; et al. Chemotherapy overcomes TRAIL-R4-mediated TRAIL resistance at the DISC level. Cell Death Differ. 2011, 18, 700-711.

25. Pan, G.; Ni, J.; Wei, Y.F.; Yu, G.; Gentz, R.; Dixit, V.M. An antagonist decoy receptor and a death domain-containing receptor for TRAIL. Science 1997, 277, 815-818.

26. Sheridan, J.P.; Marsters, S.A.; Pitti, R.M.; Gurney, A.; Skubatch, M.; Baldwin, D.; Ramakrishnan, L.; Gray, C.L.; Baker, K.; Wood, W.I.; et al. Control of TRAIL-induced apoptosis by a family of signaling and decoy receptors. Science 1997, 277, 818-821.

27. Degli-Esposti, M.A.; Dougall, W.C.; Smolak, P.J.; Waugh, J.Y.; Smith, C.A.; Goodwin, R.G. The novel receptor TRAIL-R4 induces NF-kappaB and protects against TRAIL-mediated apoptosis, yet retains an incomplete death domain. Immunity 1997, 7, 813-820.

28. Meng, R.D.; McDonald, E.R., 3rd; Sheikh, M.S.; Fornace, A.J., Jr.; El-Deiry, W.S. The TRAIL decoy receptor TRUNDD (DcR2, TRAIL-R4) is induced by adenovirus-p53 overexpression and can delay TRAIL-, p53-, and KILLER/DR5-dependent colon cancer apoptosis. Mol. Ther. 2000, $1,130-144$.

29. Emery, J.G.; McDonnell, P.; Burke, M.B.; Deen, K.C.; Lyn, S.; Silverman, C.; Dul, E.; Appelbaum, E.R.; Eichman, C.; DiPrinzio, R.; et al. Osteoprotegerin is a receptor for the cytotoxic ligand TRAIL. J. Biol. Chem. 1998, 273, 14363-14367.

30. Truneh, A.; Sharma, S.; Silverman, C.; Khandekar, S.; Reddy, M.P.; Deen, K.C.; McLaughlin, M.M.; Srinivasula, S.M.; Livi, G.P.; Marshall, L.A.; et al. Temperature-sensitive differential affinity of TRAIL for its receptors. DR5 is the highest affinity receptor. J. Biol. Chem. 2000, 275, 23319-233125.

31. Kobayashi, Y.; Udagawa, N.; Takahashi, N. Action of RANKL and OPG for osteoclastogenesis. Crit. Rev. Eukaryot. Gene Expr. 2009, 19, 61-72.

32. Bosman, M.C.; Reis, C.R.; Schuringa, J.J.; Vellenga, E.; Quax, W.J. Decreased affinity of recombinant human tumor necrosis factor-related apoptosis-inducing ligand (rhTRAIL) D269H/E195R to osteoprotegerin (OPG) overcomes TRAIL resistance mediated by the bone microenvironment. J. Biol. Chem. 2014, 289, 1071-1078.

33. Merino, D.; Lalaoui, N.; Morizot, A.; Schneider, P.; Solary, E.; Micheau, O. Differential inhibition of TRAIL-mediated DR5-DISC formation by decoy receptors 1 and 2. Mol. Cell. Biol. 2006, 26, 7046-7055.

34. Neumann, S.; Hasenauer, J.; Pollak, N.; Scheurich, P. Dominant negative effects of tumor necrosis factor (TNF)-related apoptosis-inducing ligand (TRAIL) receptor 4 on TRAIL receptor 1 signaling by formation of heteromeric complexes. J. Biol. Chem. 2014, 289, 16576-16587.

35. Shirley, S.; Morizot, A.; Micheau, O. Regulating TRAIL receptor-induced cell death at the membrane: A deadly discussion. Recent Pat. Anti-Cancer Drug Discov. 2011, 6, 311-323. 
36. O’Leary, L.; van der Sloot, A.M.; Reis, C.R.; Deegan, S.; Ryan, A.E.; Dhami, S.P.; Murillo, L.S.; Cool, R.H.; de Sampaio, P.C.; Thompson, K.; et al. Decoy receptors block TRAIL sensitivity at a supracellular level: The role of stromal cells in controlling tumour TRAIL sensitivity. Oncogene 2015, doi:10.1038/onc.2015.180.

37. Horak, P.; Pils, D.; Haller, G.; Pribill, I.; Roessler, M.; Tomek, S.; Horvat, R.; Zeillinger, R.; Zielinski, C.; Krainer, M. Contribution of epigenetic silencing of tumor necrosis factor-related apoptosis inducing ligand receptor 1 (DR4) to TRAIL resistance and ovarian cancer. Mol. Cancer Res. 2005, 3, 335-343.

38. Zhang, Y.; Zhang, B. TRAIL resistance of breast cancer cells is associated with constitutive endocytosis of death receptors 4 and 5. Mol. Cancer Res. 2008, 6, 1861-1871.

39. Lee, S.H.; Shin, M.S.; Kim, H.S.; Lee, H.K.; Park, W.S.; Kim, S.Y.; Lee, J.H.; Han, S.Y.; Park, J.Y.; Oh, R.R.; et al. Alterations of the DR5/TRAIL receptor 2 gene in non-small cell lung cancers. Cancer Res. 1999, 59, 5683-5686.

40. Hopkins-Donaldson, S.; Bodmer, J.L.; Bourloud, K.B.; Brognara, C.B.; Tschopp, J.; Gross, N. Loss of caspase- 8 expression in highly malignant human neuroblastoma cells correlates with resistance to tumor necrosis factor-related apoptosis-inducing ligand-induced apoptosis. Cancer Res. 2000, 60, 4315-4319.

41. Shirley, S.; Micheau, O. Targeting c-FLIP in cancer. Cancer Lett. 2013, 332, 141-150.

42. Zhang, X.; Jin, T.G.; Yang, H.; DeWolf, W.C.; Khosravi-Far, R.; Olumi, A.F. Persistent c-FLIP(L) expression is necessary and sufficient to maintain resistance to tumor necrosis factor-related apoptosis-inducing ligand-mediated apoptosis in prostate cancer. Cancer Res. 2004, 64, 7086-7091.

43. Irmler, M.; Thome, M.; Hahne, M.; Schneider, P.; Hofmann, K.; Steiner, V.; Bodmer, J.L.; Schroter, M.; Burns, K.; Mattmann, C.; et al. Inhibition of death receptor signals by cellular FLIP. Nature 1997, 388, 190-195.

44. Thome, M.; Schneider, P.; Hofmann, K.; Fickenscher, H.; Meinl, E.; Neipel, F.; Mattmann, C.; Burns, K.; Bodmer, J.L.; Schroter, M.; et al. Viral FLICE-inhibitory proteins (FLIPs) prevent apoptosis induced by death receptors. Nature 1997, 386, 517-521.

45. Fulda, S. Targeting c-FLICE-like inhibitory protein (CFLAR) in cancer. Expert Opin. Ther. Targets 2013, 17, 195-201.

46. Majkut, J.; Sgobba, M.; Holohan, C.; Crawford, N.; Logan, A.E.; Kerr, E.; Higgins, C.A.; Redmond, K.L.; Riley, J.S.; Stasik, I.; et al. Differential affinity of FLIP and procaspase 8 for FADD's DED binding surfaces regulates DISC assembly. Nat. Commun. 2014, 5, 3350.

47. Muzio, M.; Chinnaiyan, A.M.; Kischkel, F.C.; O’Rourke, K.; Shevchenko, A.; Ni, J.; Scaffidi, C.; Bretz, J.D.; Zhang, M.; Gentz, R.; et al. FLICE, a novel FADD-homologous ICE/CED-3-like protease, is recruited to the CD95 (Fas/APO-1) death-Inducing signaling complex. Cell 1996, $85,817-827$.

48. Micheau, O.; Thome, M.; Schneider, P.; Holler, N.; Tschopp, J.; Nicholson, D.W.; Briand, C.; Grutter, M.G. The long form of FLIP is an activator of caspase-8 at the Fas death-inducing signaling complex. J. Biol. Chem. 2002, 277, 45162-451671.

49. Chang, D.W.; Xing, Z.; Pan, Y.; Algeciras-Schimnich, A.; Barnhart, B.C.; Yaish-Ohad, S.; Peter, M.E.; Yang, X. c-FLIP(L) is a dual function regulator for caspase- 8 activation and CD95-mediated apoptosis. EMBO J. 2002, 21, 3704-3714. 
50. Pop, C.; Oberst, A.; Drag, M.; van Raam, B.J.; Riedl, S.J.; Green, D.R.; Salvesen, G.S. FLIP(L) induces caspase 8 activity in the absence of interdomain caspase 8 cleavage and alters substrate specificity. Biochem. J. 2011, 433, 447-457.

51. Estornes, Y.; Toscano, F.; Virard, F.; Jacquemin, G.; Pierrot, A.; Vanbervliet, B.; Bonnin, M.; Lalaoui, N.; Mercier-Gouy, P.; Pacheco, Y.; et al. dsRNA induces apoptosis through an atypical death complex associating TLR3 to caspase-8. Cell Death Differ. 2012, 19, 1482-1494.

52. Estornes, Y.; Aguileta, M.A.; Dubuisson, C.; de Keyser, J.; Goossens, V.; Kersse, K.; Samali, A.; Vandenabeele, P.; Bertrand, M.J. RIPK1 promotes death receptor-independent caspase-8-mediated apoptosis under unresolved ER stress conditions. Cell Death Dis. 2014, 5, doi:10.1038/cddis.2014.523.

53. Matta, H.; Eby, M.; Gazdar, A.F.; Chaudhary, P.M. Role of MRIT/cFLIP in protection against chemotherapy-induced apoptosis. Cancer Biol. Ther. 2002, 6, 652-660.

54. Wilson, C.; Wilson, T.; Johnston, P.G.; Longley, D.B.; Waugh, D.J. Interleukin-8 signaling attenuates TRAIL- and chemotherapy-induced apoptosis through transcriptional regulation of c-FLIP in prostate cancer cells. Mol. Cancer Ther. 2008, 7, 2649-2661.

55. Micheau, O.; Solary, E.; Hammann, A.; Dimanche-Boitrel, M.T. Fas ligand-independent, FADD-mediated activation of the Fas death pathway by anticancer drugs. J. Biol. Chem. 1999, 274, 7987-7992.

56. Ozoren, N.; El-Deiry, W.S. Defining characteristics of Types I and II apoptotic cells in response to TRAIL. Neoplasia (N. Y.) 2002, 4, 551-557.

57. LeBlanc, H.; Lawrence, D.; Varfolomeev, E.; Totpal, K.; Morlan, J.; Schow, P.; Fong, S.; Schwall, R.; Sinicropi, D.; Ashkenazi, A. Tumor-cell resistance to death receptor-Induced apoptosis through mutational inactivation of the proapoptotic Bcl-2 homolog Bax. Nat. Med. 2002, 8, 274-281.

58. Fulda, S.; Meyer, E.; Debatin, K.M. Inhibition of TRAIL-induced apoptosis by Bcl-2 overexpression. Oncogene 2002, 21, 2283-2294.

59. Taniai, M.; Grambihler, A.; Higuchi, H.; Werneburg, N.; Bronk, S.F.; Farrugia, D.J.; Kaufmann, S.H.; Gores, G.J. Mcl-1 mediates tumor necrosis factor-related apoptosis-inducing ligand resistance in human cholangiocarcinoma cells. Cancer Res. 2004, 64, 3517-3524.

60. Hinz, S.; Trauzold, A.; Boenicke, L.; Sandberg, C.; Beckmann, S.; Bayer, E.; Walczak, H.; Kalthoff, H.; Ungefroren, H. Bcl-XL protects pancreatic adenocarcinoma cells against CD95- and TRAIL-receptor-mediated apoptosis. Oncogene 2000, 19, 5477-5486.

61. Chawla-Sarkar, M.; Bae, S.I.; Reu, F.J.; Jacobs, B.S.; Lindner, D.J.; Borden, E.C. Downregulation of Bcl-2, FLIP or IAPs (XIAP and survivin) by siRNAs sensitizes resistant melanoma cells to Apo2L/TRAIL-induced apoptosis. Cell Death Differ. 2004, 11, 915-923.

62. Kim, E.H.; Kim, S.U.; Shin, D.Y.; Choi, K.S. Roscovitine sensitizes glioma cells to TRAIL-mediated apoptosis by downregulation of survivin and XIAP. Oncogene 2004, 23, 446-456.

63. Kim, E.H.; Kim, H.S.; Kim, S.U.; Noh, E.J.; Lee, J.S.; Choi, K.S. Sodium butyrate sensitizes human glioma cells to TRAIL-mediated apoptosis through inhibition of Cdc2 and the subsequent downregulation of survivin and XIAP. Oncogene 2005, 24, 6877-6889. 
64. Van Valen, F.; Fulda, S.; Schafer, K.L.; Truckenbrod, B.; Hotfilder, M.; Poremba, C.; Debatin, K.M.; Winkelmann, W. Selective and nonselective toxicity of TRAIL/Apo2L combined with chemotherapy in human bone tumour cells vs. normal human cells. Int. J. Cancer 2003, 107, 929-940.

65. Jacquemin, G.; Granci, V.; Gallouet, A.S.; Lalaoui, N.; Morle, A.; Iessi, E.; Morizot, A.; Garrido, C.; Guillaudeux, T.; Micheau, O. Quercetin-mediated Mcl-1 and survivin downregulation restores TRAIL-induced apoptosis in non-Hodgkin's lymphoma B cells. Haematologica 2012, 97, 38-46.

66. Morlé, A.; Garrido, C.; Micheau, O. Hyperthermia restores apoptosis induced by death receptors through aggregation-induced c-FLIP cytosolic depletion. Cell Death Dis. 2015, 6, doi:10.1038/cddis.2015.12.

67. Pavet, V.; Beyrath, J.; Pardin, C.; Morizot, A.; Lechner, M.-C.; Briand, J.-P.; Wendland, M.; Maison, W.; Fournel, S.; Micheau, O.; et al. Multivalent DR5 peptides activate the TRAIL death pathway and exert tumoricidal activity. Cancer Res. 2010, 70, 1101-1110.

68. Zakaria, A.B.; Picaud, F.; Rattier, T.; Pudlo, M.; Dufour, F.; Saviot, L.; Chassagnon, R.; Lherminier, J.; Gharbi, T.; Micheau, O.; Herlem, G. Nanovectorization of TRAIL with single wall carbon nanotubes enhances tumor cell killing. Nano Lett. 2015, 15, 891-895.

69. Reis, C.R.; van der Sloot, A.M.; Natoni, A.; Szegezdi, E.; Setroikromo, R.; Meijer, M.; Sjollema, K.; Stricher, F.; Cool, R.H.; Samali, A.; et al. Rapid and efficient cancer cell killing mediated by high-affinity death receptor homotrimerizing TRAIL variants. Cell Death Dis. 2010, 1, e83.

70. Tur, V.; van der Sloot, A.M.; Reis, C.R.; Szegezdi, E.; Cool, R.H.; Samali, A.; Serrano, L.; Quax, W.J. DR4-selective tumor necrosis factor-related apoptosis-inducing ligand (TRAIL) variants obtained by structure-based design. J. Biol. Chem. 2008, 283, 20560-20568.

71. Seifert, O.; Pollak, N.; Nusser, A.; Steiniger, F.; Ruger, R.; Pfizenmaier, K.; Kontermann, R.E. Immuno-LipoTRAIL: Targeted delivery of TRAIL-functionalized liposomal nanoparticles. Bioconjug. Chem. 2014, 25, 879-887.

72. Yang, S.; Cui, J. Fusion Protein Comprising Circularly Permuted form of Trail/Apo21, Coding Gene and Use Thereof. WO 2013037090 A1, 21 March 2013.

73. El Fajoui, Z.; Toscano, F.; Jacquemin, G.; Abello, J.; Scoazec, J.Y.; Micheau, O.; Saurin, J.C. Oxaliplatin Sensitizes Human Colon Cancer Cells to TRAIL Through JNK-Dependent Phosphorylation of Bcl-xL. Gastroenterology 2011, 141, 663-673.

74. Ding, L.; Yuan, C.; Wei, F.; Wang, G.; Zhang, J.; Bellail, A.C.; Zhang, Z.; Olson, J.J.; Hao, C. Cisplatin restores TRAIL apoptotic pathway in glioblastoma-derived stem cells through up-regulation of DR5 and down-regulation of c-FLIP. Cancer Investig. 2011, 29, 511-520.

75. Hetschko, H.; Voss, V.; Seifert, V.; Prehn, J.H.; Kogel, D. Upregulation of DR5 by proteasome inhibitors potently sensitizes glioma cells to TRAIL-induced apoptosis. FEBS J. 2008, 275, 1925-1936.

76. Hu, R.; Yang, Y.; Liu, Z.; Jiang, H.; Zhu, K.; Li, J.; Xu, W. The XIAP inhibitor Embelin enhances TRAIL-induced apoptosis in human leukemia cells by DR4 and DR5 upregulation. Tumour Biol.: J. Int. Soc. Oncodev. Biol. Med. 2015, 36, 769-777.

77. Lee, S.J.; Kim, E.A.; Song, K.S.; Kim, M.J.; Lee, D.H.; Kwon, T.K.; Lee, T.J. Antimycin A sensitizes cells to TRAIL-induced apoptosis through upregulation of DR5 and downregulation of c-FLIP and Bcl-2. Int. J. Oncol. 2012, 41, 1425-1430. 
78. Moon, D.O.; Kim, M.O.; Choi, Y.H.; Kim, G.Y. Butein sensitizes human hepatoma cells to TRAIL-induced apoptosis via extracellular signal-regulated kinase/Sp1-dependent DR5 upregulation and NF-kappaB inactivation. Mol. Cancer Ther. 2010, 9, 1583-1595.

79. Park, E.J.; Choi, K.S.; Yoo, Y.H.; Kwon, T.K. Nutlin-3, a small-molecule MDM2 inhibitor, sensitizes Caki cells to TRAIL-induced apoptosis through p53-mediated PUMA upregulation and ROS-mediated DR5 upregulation. Anticancer Drugs 2013, 24, 260-269.

80. Portanova, P.; Notaro, A.; Pellerito, O.; Sabella, S.; Giuliano, M.; Calvaruso, G. Notch inhibition restores TRAIL-mediated apoptosis via AP1-dependent upregulation of DR4 and DR5 TRAIL receptors in MDA-MB-231 breast cancer cells. Int. J. Oncol. 2013, 43, 121-130.

81. Ganten, T.M.; Haas, T.L.; Sykora, J.; Stahl, H.; Sprick, M.R.; Fas, S.C.; Krueger, A.; Weigand, M.A.; Grosse-Wilde, A.; Stremmel, W.; et al. Enhanced caspase- 8 recruitment to and activation at the DISC is critical for sensitisation of human hepatocellular carcinoma cells to TRAIL-induced apoptosis by chemotherapeutic drugs. Cell Death Differ. 2004, 11 (Suppl. S1), S86-S96.

82. Carlisi, D.; Lauricella, M.; D’Anneo, A.; Emanuele, S.; Angileri, L.; di Fazio, P.; Santulli, A.; Vento, R.; Tesoriere, G. The histone deacetylase inhibitor suberoylanilide hydroxamic acid sensitises human hepatocellular carcinoma cells to TRAIL-induced apoptosis by TRAIL-DISC activation. Eur. J. Cancer 2009, 45, 2425-2438.

83. Fukazawa, T.; Fujiwara, T.; Uno, F.; Teraishi, F.; Kadowaki, Y.; Itoshima, T.; Takata, Y.; Kagawa, S.; Roth, J.A.; Tschopp, J.; Tanaka, N. Accelerated degradation of cellular FLIP protein through the ubiquitin- proteasome pathway in p53-mediated apoptosis of human cancer cells. Oncogene 2001, 20, 5225-5231.

84. Han, M.H.; Park, C.; Kwon, T.K.; Kim, G.Y.; Kim, W.J.; Hong, S.H.; Yoo, Y.H.; Choi, Y.H. The Histone Deacetylase Inhibitor Trichostatin A Sensitizes Human Renal Carcinoma Cells to TRAIL-Induced Apoptosis through Down-Regulation of c-FLIPL. Biomol. Ther. (Seoul) 2015, 23, 31-38.

85. Sanchez-Perez, T.; Ortiz-Ferron, G.; Lopez-Rivas, A. Mitotic arrest and JNK-induced proteasomal degradation of FLIP and Mcl-1 are key events in the sensitization of breast tumor cells to TRAIL by antimicrotubule agents. Cell Death Differ. 2010, 17, 883-894.

86. Song, X.; Kim, S.Y.; Lee, Y.J. Evidence for two modes of synergistic induction of apoptosis by mapatumumab and oxaliplatin in combination with hyperthermia in human colon cancer cells. PLoS ONE 2013, 8, doi:10.1371/journal.pone.0073654.

87. Kim, Y.; Suh, N.; Sporn, M.; Reed, J.C. An inducible pathway for degradation of FLIP protein sensitizes tumor cells to TRAIL-induced apoptosis. J. Biol. Chem. 2002, 277, 22320-22329.

88. Kim, Y.S.; Kim, E.A.; Park, K.G.; Lee, S.J.; Kim, M.S.; Sohn, H.Y.; Lee, T.J. Dioscin sensitizes cells to TRAIL-induced apoptosis through downregulation of c-FLIP and Bcl-2. Oncol. Rep. 2012, 28, 1910-1916.

89. Wilkie-Grantham, R.P.; Matsuzawa, S.; Reed, J.C. Novel phosphorylation and ubiquitination sites regulate reactive oxygen species-dependent degradation of anti-apoptotic c-FLIP protein. J. Biol. Chem. 2013, 288, 12777-127790. 
90. Henson, E.S.; Gibson, E.M.; Villanueva, J.; Bristow, N.A.; Haney, N.; Gibson, S.B. Increased expression of Mcl-1 is responsible for the blockage of TRAIL-induced apoptosis mediated by EGF/ErbB1 signaling pathway. J. Cell. Biochem. 2003, 89, 1177-1192.

91. Azijli, K.; Yuvaraj, S.; van Roosmalen, I.; Flach, K.; Giovannetti, E.; Peters, G.J.; de Jong, S.; Kruyt, F.A. MAPK p38 and JNK have opposing activities on TRAIL-induced apoptosis activation in NSCLC H460 cells that involves RIP1 and caspase- 8 and is mediated by Mcl-1. Apoptosis 2013, 18, 851-860.

92. Ndozangue-Touriguine, O.; Sebbagh, M.; Merino, D.; Micheau, O.; Bertoglio, J.; Breard, J. A mitochondrial block and expression of XIAP lead to resistance to TRAIL-induced apoptosis during progression to metastasis of a colon carcinoma. Oncogene 2008, 27, 6012-6022.

93. Stadel, D.; Mohr, A.; Ref, C.; MacFarlane, M.; Zhou, S.; Humphreys, R.; Bachem, M.; Cohen, G.; Moller, P.; Zwacka, R.M.; et al. TRAIL-induced apoptosis is preferentially mediated via TRAIL receptor 1 in pancreatic carcinoma cells and profoundly enhanced by XIAP inhibitors. Clin. Cancer Res. 2010, 16, 5734-5749.

94. Son, Y.G.; Kim, E.H.; Kim, J.Y.; Kim, S.U.; Kwon, T.K.; Yoon, A.R.; Yun, C.O.; Choi, K.S. Silibinin sensitizes human glioma cells to TRAIL-mediated apoptosis via DR5 up-regulation and down-regulation of c-FLIP and survivin. Cancer Res. 2007, 67, 8274-8284.

95. Falschlehner, C.; Emmerich, C.H.; Gerlach, B.; Walczak, H. TRAIL signalling: Decisions between life and death. Int. J. Biochem. Cell Biol. 2007, 39, 1462-1475.

96. Geismann, C.; Grohmann, F.; Sebens, S.; Wirths, G.; Dreher, A.; Hasler, R.; Rosenstiel, P.; Hauser, C.; Egberts, J.H.; Trauzold, A.; et al. c-Rel is a critical mediator of NF-kappaB-dependent TRAIL resistance of pancreatic cancer cells. Cell Death Dis. 2014, 5, e1455. doi:10.1038/cddis.2014.417.

97. Zauli, G.; Sancilio, S.; Cataldi, A.; Sabatini, N.; Bosco, D.; di Pietro, R. PI-3K/Akt and NF-kappaB/IkappaBalpha pathways are activated in Jurkat $\mathrm{T}$ cells in response to TRAIL treatment. J. Cell. Physiol. 2005, 202, 900-911.

98. Trauzold, A.; Wermann, H.; Arlt, A.; Schutze, S.; Schafer, H.; Oestern, S.; Roder, C.; Ungefroren, H.; Lampe, E.; Heinrich, M.; et al. CD95 and TRAIL receptor-mediated activation of protein kinase $\mathrm{C}$ and NF-kappaB contributes to apoptosis resistance in ductal pancreatic adenocarcinoma cells. Oncogene 2001, 20, 4258-4269.

99. Tran, S.E.; Holmstrom, T.H.; Ahonen, M.; Kahari, V.M.; Eriksson, J.E. MAPK/ERK overrides the apoptotic signaling from Fas, TNF, and TRAIL receptors. J. Biol. Chem. 2001, 276, 16484-16490.

100. Secchiero, P.; Melloni, E.; Heikinheimo, M.; Mannisto, S.; di Pietro, R.; Iacone, A.; Zauli, G. TRAIL regulates normal erythroid maturation through an ERK-dependent pathway. Blood 2004, 103, 517-522.

101. Secchiero, P.; Gonelli, A.; Carnevale, E.; Milani, D.; Pandolfi, A.; Zella, D.; Zauli, G. TRAIL promotes the survival and proliferation of primary human vascular endothelial cells by activating the Akt and ERK pathways. Circulation 2003, 107, 2250-2256.

102. Song, J.J.; Kim, J.H.; Sun, B.K.; Alcala, M.A., Jr.; Bartlett, D.L.; Lee, Y.J. c-Cbl acts as a mediator of Src-induced activation of the PI3K-Akt signal transduction pathway during TRAIL treatment. Cell Signal. 2010, 22, 377-385. 
103. Varfolomeev, E.; Maecker, H.; Sharp, D.; Lawrence, D.; Renz, M.; Vucic, D.; Ashkenazi, A. Molecular determinants of kinase pathway activation by Apo2 ligand/tumor necrosis factor-related apoptosis-inducing ligand. J. Biol. Chem. 2005, 280, 40599-40608.

104. Cargnello, M.; Roux, P.P. Activation and function of the MAPKs and their substrates, the MAPK-activated protein kinases. Microbiol. Mol. Biol. Rev. 2011, 75, 50-83.

105. Cossa, G.; Gatti, L.; Cassinelli, G.; Lanzi, C.; Zaffaroni, N.; Perego, P. Modulation of sensitivity to antitumor agents by targeting the MAPK survival pathway. Curr. Pharm. Des. 2013, 19, 883-894.

106. Ichijo, H. From receptors to stress-activated MAP kinases. Oncogene 1999, 18, 6087-6093.

107. Zhang, X.D.; Borrow, J.M.; Zhang, X.Y.; Nguyen, T.; Hersey, P. Activation of ERK1/2 protects melanoma cells from TRAIL-induced apoptosis by inhibiting Smac/DIABLO release from mitochondria. Oncogene 2003, 22, 2869-2881.

108. Seidelin, J.B.; Coskun, M.; Vainer, B.; Riis, L.; Soendergaard, C.; Nielsen, O.H. ERK controls epithelial cell death receptor signalling and cellular FLICE-like inhibitory protein (c-FLIP) in ulcerative colitis. J. Mol. Med. (Berl.) 2013, 91, 839-849.

109. Gupta, S.C.; Francis, S.K.; Nair, M.S.; Mo, Y.Y.; Aggarwal, B.B. Azadirone, a limonoid tetranortriterpene, induces death receptors and sensitizes human cancer cells to tumor necrosis factor-related apoptosis-inducing ligand (TRAIL) through a p53 protein-independent mechanism: Evidence for the role of the ROS-ERK-CHOP-death receptor pathway. J. Biol. Chem. 2013, 288, 32343-32356.

110. Gupta, S.C.; Reuter, S.; Phromnoi, K.; Park, B.; Hema, P.S.; Nair, M.; Aggarwal, B.B. Nimbolide sensitizes human colon cancer cells to TRAIL through reactive oxygen species- and ERK-dependent up-regulation of death receptors, p53, and Bax. J. Biol. Chem. 2011, 286, 1134-1146.

111. Kang, C.H.; Moon, D.O.; Choi, Y.H.; Choi, I.W.; Moon, S.K.; Kim, W.J.; Kim, G.Y. Piceatannol enhances TRAIL-induced apoptosis in human leukemia THP-1 cells through Sp1- and ERK-dependent DR5 up-regulation. Toxicol. In Vitro 2011, 25, 605-612.

112. Kim, E.Y.; Yu, J.S.; Yang, M.; Kim, A.K. Sub-toxic dose of apigenin sensitizes HepG2 cells to TRAIL through ERK-dependent up-regulation of TRAIL receptor DR5. Mol. Cells 2013, 35, $32-40$.

113. Lim, S.C.; Duong, H.Q.; Parajuli, K.R.; Han, S.I. Pro-apoptotic role of the MEK/ERK pathway in ursodeoxycholic acid-induced apoptosis in SNU601 gastric cancer cells. Oncol. Rep. 2012, 28, 1429-1434.

114. Oh, Y.T.; Liu, X.; Yue, P.; Kang, S.; Chen, J.; Taunton, J.; Khuri, F.R.; Sun, S.Y. ERK/ribosomal S6 kinase (RSK) signaling positively regulates death receptor 5 expression through co-activation of CHOP and Elk1. J. Biol. Chem. 2010, 285, 41310-41319.

115. Oh, Y.T.; Yue, P.; Zhou, W.; Balko, J.M.; Black, E.P.; Owonikoko, T.K.; Khuri, F.R.; Sun, S.Y. Oncogenic Ras and B-Raf proteins positively regulate death receptor 5 expression through co-activation of ERK and JNK signaling. J. Biol. Chem. 2012, 287, 257-267.

116. Sung, B.; Ravindran, J.; Prasad, S.; Pandey, M.K.; Aggarwal, B.B. Gossypol induces death receptor-5 through activation of the ROS-ERK-CHOP pathway and sensitizes colon cancer cells to TRAIL. J. Biol. Chem. 2010, 285, 35418-35427. 
117. Muhlenbeck, F.; Haas, E.; Schwenzer, R.; Schubert, G.; Grell, M.; Smith, C.; Scheurich, P.; Wajant, H. TRAIL/Apo2L activates c-Jun $\mathrm{NH}_{2}$-terminal kinase (JNK) via caspase-dependent and caspase-independent pathways. J. Biol. Chem. 1998, 273, 33091-33098.

118. He, W.; Wang, Q.; Xu, J.; Xu, X.; Padilla, M.T.; Ren, G.; Gou, X.; Lin, Y. Attenuation of TNFSF10/TRAIL-induced apoptosis by an autophagic survival pathway involving TRAF2- and RIPK1/RIP1-mediated MAPK8/JNK activation. Autophagy 2012, 8, 1811-1821.

119. Zhang, L.; Dittmer, M.R.; Blackwell, K.; Workman, L.M.; Hostager, B.; Habelhah, H. TRAIL activates JNK and NF-kappaB through RIP1-dependent and -independent pathways. Cell Signal. 2015, 27, 306-314.

120. Allen, J.E.; El-Deiry, W.S. Oxaliplatin uses JNK to restore TRAIL sensitivity in cancer cells through Bcl-xL inactivation. Gastroenterology 2011, 141, 430-434.

121. Lin, F.L.; Hsu, J.L.; Chou, C.H.; Wu, W.J.; Chang, C.I.; Liu, H.J. Activation of p38 MAPK by damnacanthal mediates apoptosis in SKHep 1 cells through the DR5/TRAIL and TNFR1/TNF-alpha and p53 pathways. Eur. J. Pharmacol. 2011, 650, 120-129.

122. Liu, J.; Ma, L.; Wu, N.; Liu, G.; Zheng, L.; Lin, X. Aplysin sensitizes cancer cells to TRAIL by suppressing P38 MAPK/survivin pathway. Mar. Drugs 2014, 12, 5072-5088.

123. Kim, E.Y.; Ryu, J.H.; Kim, A.K. CAPE promotes TRAIL-induced apoptosis through the upregulation of TRAIL receptors via activation of p38 and suppression of JNK in SK-Hep1 hepatocellular carcinoma cells. Int. J. Oncol. 2013, 43, 1291-1300.

124. Lepage, C.; Leger, D.Y.; Bertrand, J.; Martin, F.; Beneytout, J.L.; Liagre, B. Diosgenin induces death receptor-5 through activation of p38 pathway and promotes TRAIL-induced apoptosis in colon cancer cells. Cancer Lett. 2011, 301, 193-202.

125. Jin, C.Y.; Park, C.; Kim, G.Y.; Lee, S.J.; Kim, W.J.; Choi, Y.H. Genistein enhances TRAIL-induced apoptosis through inhibition of p38 MAPK signaling in human hepatocellular carcinoma Hep3B cells. Chem. Biol. Interact. 2009, 180, 143-150.

126. Do, M.T.; Na, M.; Kim, H.G.; Khanal, T.; Choi, J.H.; Jin, S.W.; Oh, S.H.; Hwang, I.H.; Chung, Y.C.; Kim, H.S.; et al. Ilimaquinone induces death receptor expression and sensitizes human colon cancer cells to TRAIL-induced apoptosis through activation of ROS-ERK/p38 MAPK-CHOP signaling pathways. Food Chem. Toxicol. 2014, 71, 51-59.

127. Abdollahi, T.; Robertson, N.M.; Abdollahi, A.; Litwack, G. Inhibition of TRAIL-induced apoptosis by IL-8 is mediated by the p38-MAPK pathway in OVCAR3 cells. Apoptosis 2005, 10, 1383-1393.

128. Lee, M.W.; Park, S.C.; Yang, Y.G.; Yim, S.O.; Chae, H.S.; Bach, J.H.; Lee, H.J.; Kim, K.Y.; Lee, W.B.; Kim, S.S. The involvement of reactive oxygen species (ROS) and p38 mitogen-activated protein (MAP) kinase in TRAIL/Apo2L-induced apoptosis. FEBS Lett. 2002, 512, 313-318.

129. Herr, I.; Wilhelm, D.; Meyer, E.; Jeremias, I.; Angel, P.; Debatin, K.M. JNK/SAPK activity contributes to TRAIL-induced apoptosis. Cell Death Differ. 1999, 6, 130-135.

130. Woo, J.S.; Kim, S.M.; Jeong, C.H.; Ryu, C.H.; Jeun, S.S. Lipoxygenase inhibitor MK886 potentiates TRAIL-induced apoptosis through CHOP- and p38 MAPK-mediated up-regulation of death receptor 5 in malignant glioma. Biochem. Biophys. Res. Commun. 2013, 431, 354-359. 
131. Lamy, V.; Bousserouel, S.; Gosse, F.; Minker, C.; Lobstein, A.; Raul, F. Lupulone triggers p38 MAPK-controlled activation of p53 and of the TRAIL receptor apoptotic pathway in human colon cancer-derived metastatic cells. Oncol. Rep. 2011, 26, 109-114.

132. Weldon, C.B.; Parker, A.P.; Patten, D.; Elliott, S.; Tang, Y.; Frig..o, D.E.; Dugan, C.M.; Coakley, E.L.; Butler, N.N.; Clayton, J.L.; et al. Sensitization of apoptotically-resistant breast carcinoma cells to TNF and TRAIL by inhibition of p38 mitogen-activated protein kinase signaling. Int. J. Oncol. 2004, 24, 1473-1480.

133. Pennati, M.; Sbarra, S.; de Cesare, M.; Lopergolo, A.; Locatelli, S.L.; Campi, E.; Daidone, M.G.; Carlo-Stella, C.; Gianni, A.M.; Zaffaroni, N. YM155 sensitizes triple-negative breast cancer to membrane-bound TRAIL through p38 MAPK- and CHOP-mediated DR5 upregulation. Int. J. Cancer 2015, 136, 299-309.

134. Manning, B.D.; Cantley, L.C. AKT/PKB signaling: Navigating downstream. Cell 2007, 129, 1261-1274.

135. Mayer, I.A.; Arteaga, C.L. The PI3K/AKT Pathway as a Target for Cancer Treatment. Annu. Rev. Med. 2015. doi:10.1146/annurev-med-062913-051343.

136. Hers, I.; Vincent, E.E.; Tavare, J.M. Akt signalling in health and disease. Cell Signal. 2011, 23, $1515-1527$.

137. Kang, Y.C.; Kim, K.M.; Lee, K.S.; Namkoong, S.; Lee, S.J.; Han, J.A.; Jeoung, D.; Ha, K.S.; Kwon, Y.G.; Kim, Y.M. Serum bioactive lysophospholipids prevent TRAIL-induced apoptosis via PI3K/Akt-dependent cFLIP expression and Bad phosphorylation. Cell Death Differ. 2004, 11, 1287-1298.

138. Kobayashi, S.; Werneburg, N.W.; Bronk, S.F.; Kaufmann, S.H.; Gores, G.J. Interleukin-6 contributes to Mcl-1 up-regulation and TRAIL resistance via an Akt-signaling pathway in cholangiocarcinoma cells. Gastroenterology 2005, 128, 2054-2065.

139. Lalaoui, N.; Morle, A.; Merino, D.; Jacquemin, G.; Iessi, E.; Morizot, A.; Shirley, S.; Robert, B.; Solary, E.; Garrido, C.; Micheau, O. TRAIL-R4 promotes tumor growth and resistance to apoptosis in cervical carcinoma HeLa cells through AKT. PLoS ONE 2011, 6, e19679.

140. Nam, S.Y.; Amoscato, A.A.; Lee, Y.J. Low glucose-enhanced TRAIL cytotoxicity is mediated through the ceramide-Akt-FLIP pathway. Oncogene 2002, 21, 337-346.

141. Nam, S.Y.; Jung, G.A.; Hur, G.C.; Chung, H.Y.; Kim, W.H.; Seol, D.W.; Lee, B.L. Upregulation of FLIP(S) by Akt, a possible inhibition mechanism of TRAIL-induced apoptosis in human gastric cancers. Cancer Sci. 2003, 94, 1066-1073.

142. Panner, A.; Crane, C.A.; Weng, C.; Feletti, A.; Fang, S.; Parsa, A.T.; Pieper, R.O. Ubiquitin-specific protease 8 links the PTEN-Akt-AIP4 pathway to the control of FLIPS stability and TRAIL sensitivity in glioblastoma multiforme. Cancer Res. 2010, 70, 5046-5053.

143. Skurk, C.; Maatz, H.; Kim, H.S.; Yang, J.; Abid, M.R.; Aird, W.C.; Walsh, K. The Akt-regulated forkhead transcription factor FOXO3a controls endothelial cell viability through modulation of the caspase-8 inhibitor FLIP. J. Biol. Chem. 2004, 279, 1513-1525.

144. Wang, X.; Chen, W.; Zeng, W.; Bai, L.; Tesfaigzi, Y.; Belinsky, S.A.; Lin, Y. Akt-mediated eminent expression of c-FLIP and Mcl-1 confers acquired resistance to TRAIL-induced cytotoxicity to lung cancer cells. Mol. Cancer Ther. 2008, 7, 1156-1163. 
145. Hayden, M.S.; Ghosh, S. Regulation of NF-kappaB by TNF family cytokines. Semin. Immunol. 2014, 26, 253-266.

146. Smale, S.T. Dimer-specific regulatory mechanisms within the NF-kappaB family of transcription factors. Immunol. Rev. 2012, 246, 193-204.

147. Razani, B.; Reichardt, A.D.; Cheng, G. Non-canonical NF-kappaB signaling activation and regulation: Principles and perspectives. Immunol. Rev. 2011, 244, 44-54.

148. Napetschnig, J.; Wu, H. Molecular basis of NF-kappaB signaling. Annu. Rev. Biophys. 2013, 42, 443-468.

149. Bender, K.; Gottlicher, M.; Whiteside, S.; Rahmsdorf, H.J.; Herrlich, P. Sequential DNA damage-independent and -dependent activation of NF-kappaB by UV. EMBO J. 1998, 17, 5170-5181.

150. Shimada, T.; Kawai, T.; Takeda, K.; Matsumoto, M.; Inoue, J.; Tatsumi, Y.; Kanamaru, A.; Akira, S. IKK-i, a novel lipopolysaccharide-inducible kinase that is related to IkappaB kinases. Int. Immunol. 1999, 11, 1357-1362.

151. Vuillard, L.; Nicholson, J.; Hay, R.T. A complex containing betaTrCP recruits Cdc34 to catalyse ubiquitination of IkappaBalpha. FEBS Lett. 1999, 455, 311-314.

152. Oeckinghaus, A.; Hayden, M.S.; Ghosh, S. Crosstalk in NF-kappaB signaling pathways. Nat. Immunol. 2011, 12, 695-708.

153. Zarnegar, B.J.; Wang, Y.; Mahoney, D.J.; Dempsey, P.W.; Cheung, H.H.; He, J.; Shiba, T.; Yang, X.; Yeh, W.C.; Mak, T.W.; et al. Noncanonical NF-kappaB activation requires coordinated assembly of a regulatory complex of the adaptors cIAP1, cIAP2, TRAF2 and TRAF3 and the kinase NIK. Nat. Immunol. 2008, 9, 1371-1378.

154. Betts, J.C.; Nabel, G.J. Differential regulation of NF-kappaB2(p100) processing and control by amino-terminal sequences. Mol. Cell. Biol. 1996, 16, 6363-6371.

155. Bortul, R.; Tazzari, P.L.; Cappellini, A.; Tabellini, G.; Billi, A.M.; Bareggi, R.; Manzoli, L.; Cocco, L.; Martelli, A.M. Constitutively active Akt1 protects HL60 leukemia cells from TRAIL-induced apoptosis through a mechanism involving NF-kappaB activation and cFLIP(L) up-regulation. Leukemia 2003, 17, 379-389.

156. Morales, J.C.; Ruiz-Magana, M.J.; Ruiz-Ruiz, C. Regulation of the resistance to TRAIL-induced apoptosis in human primary T lymphocytes: Role of NF-kappaB inhibition. Mol. Immunol. 2007, 44, 2587-2597.

157. Travert, M.; Ame-Thomas, P.; Pangault, C.; Morizot, A.; Micheau, O.; Semana, G.; Lamy, T.; Fest, T.; Tarte, K.; Guillaudeux, T. CD40 ligand protects from TRAIL-induced apoptosis in follicular lymphomas through NF-kappaB activation and up-regulation of c-FLIP and Bcl-xL. J. Immunol. 2008, 181, 1001-1011.

158. Ge, R.; Wang, Z.; Zeng, Q.; Xu, X.; Olumi, A.F. F-box protein 10, an NF-kappaB-dependent anti-apoptotic protein, regulates TRAIL-induced apoptosis through modulating c-Fos/c-FLIP pathway. Cell Death Differ. 2011, 18, 1184-1195.

159. Seol, J.Y.; Mihich, E.; Berleth, E.S. TNF Apoptosis Protection Fraction (TAPF) prevents apoptosis induced by TNF, but not by Fas or TRAIL, via NF-kappaB-induced increase in cFLIP. Cytokine 2015, 75, 321-329. 
160. Grunert, M.; Gottschalk, K.; Kapahnke, J.; Gundisch, S.; Kieser, A.; Jeremias, I. The adaptor protein FADD and the initiator caspase- 8 mediate activation of NF-kappaB by TRAIL. Cell Death Dis. 2012, 3, e414. doi:10.1038/cddis.2012.154.

161. Keane, M.M.; Rubinstein, Y.; Cuello, M.; Ettenberg, S.A.; Banerjee, P.; Nau, M.M.; Lipkowitz, S. Inhibition of NF-kappaB activity enhances TRAIL mediated apoptosis in breast cancer cell lines. Breast Cancer Res. Treat. 2000, 64, 211-219.

162. Ravi, R.; Bedi, G.C.; Engstrom, L.W.; Zeng, Q.; Mookerjee, B.; Gelinas, C.; Fuchs, E.J.; Bedi, A. Regulation of death receptor expression and TRAIL/Apo2L-induced apoptosis by NF-kappaB. Nat. Cell Biol. 2001, 3, 409-416.

163. Lluis, J.M.; Nachbur, U.; Cook, W.D.; Gentle, I.E.; Moujalled, D.; Moulin, M.; Wong, W.W.; Khan, N.; Chau, D.; Callus, B.A.; et al. TAK1 is required for survival of mouse fibroblasts treated with TRAIL, and does so by NF-kappaB dependent induction of cFLIPL. PLoS ONE 2010, 5, doi:10.1371/journal.pone.0008620.

164. Kim, J.Y.; Lee, J.Y.; Kim, D.G.; Koo, G.B.; Yu, J.W.; Kim, Y.S. TRADD is critical for resistance to TRAIL-induced cell death through NF-kappaB activation. FEBS Lett. 2011, 585, 2144-2150.

165. Ehrhardt, H.; Fulda, S.; Schmid, I.; Hiscott, J.; Debatin, K.M.; Jeremias, I. TRAIL induced survival and proliferation in cancer cells resistant towards TRAIL-induced apoptosis mediated by NF-kappaB. Oncogene 2003, 22, 3842-3852.

166. Jennewein, C.; Karl, S.; Baumann, B.; Micheau, O.; Debatin, K.M.; Fulda, S. Identification of a novel pro-apoptotic role of NF-kappaB in the regulation of TRAIL- and CD95-mediated apoptosis of glioblastoma cells. Oncogene 2012, 31, 1468-1474.

167. Micheau, O.; Shirley, S.; Dufour, F. Death receptors as targets in cancer. Br. J. Pharmacol. 2013, 169, 1723-1744.

168. Lim, B.; Allen, J.E.; Prabhu, V.V.; Talekar, M.K.; Finnberg, N.K.; El-Deiry, W.S. Targeting TRAIL in the treatment of cancer: New developments. Expert Opin. Ther. Targets 2015, 19, 1171-1185.

169. Jacquemin, G.; Shirley, S.; Micheau, O. Combining naturally occurring polyphenols with TNF-related apoptosis-inducing ligand: A promising approach to kill resistant cancer cells? Cellul. Mol. Life Sci. 2010, 67, 3115-3130.

170. Ishibashi, M.; Ohtsuki, T. Studies on search for bioactive natural products targeting TRAIL signaling leading to tumor cell apoptosis. Med. Res. Rev. 2008, 28, 688-714.

171. Farooqi, A.A.; Attar, R.; Gasparri, M.L. Drugs from marine sources: Modulation of TRAIL induced apoptosis in cancer cells. Asian Pac. J. Cancer Prev. 2014, 15, 9045-9047.

172. Farooqi, A.A.; Fayyaz, S.; Hou, M.F.; Li, K.T.; Tang, J.Y.; Chang, H.W. Reactive oxygen species and autophagy modulation in non-marine drugs and marine drugs. Mar. Drugs 2014, 12, 5408-5424.

173. Sithranga Boopathy, N.; Kathiresan, K. Anticancer drugs from marine flora: An overview. J. Oncol. 2010, 2010, 214186.

174. Gordaliza, M. Natural products as leads to anticancer drugs. Clin. Transl. Oncol. 2007, 9, 767-776.

175. Kinghorn, A.D.; Chin, Y.W.; Swanson, S.M. Discovery of natural product anticancer agents from biodiverse organisms. Curr. Opin. Drug Discov. Dev. 2009, 12, 189-196. 
176. Nikapitiya, C. Bioactive secondary metabolites from marine microbes for drug discovery. Adv. Food Nutr. Res. 2012, 65, 363-387.

177. Leal, M.C.; Puga, J.; Serodio, J.; Gomes, N.C.; Calado, R. Trends in the discovery of new marine natural products from invertebrates over the last two decades-Where and what are we bioprospecting? PLoS ONE 2012, 7, doi:10.1371/journal.pone.0030580.

178. Proksch, P.; Ebel, R.; Edrada, R.A.; Wray, V.; Steube, K. Bioactive natural products from marine invertebrates and associated fungi. Prog. Mol. Subcell. Biol. 2003, 37, 117-142.

179. Mitsiades, C.S.; Ocio, E.M.; Pandiella, A.; Maiso, P.; Gajate, C.; Garayoa, M.; Vilanova, D.; Montero, J.C.; Mitsiades, N.; McMullan, C.J.; et al. Aplidin, a marine organism-derived compound with potent antimyeloma activity in vitro and in vivo. Cancer Res. 2008, 68, 5216-5125.

180. Guzman, E.A.; Johnson, J.D.; Linley, P.A.; Gunasekera, S.E.; Wright, A.E. A novel activity from an old compound: Manzamine A reduces the metastatic potential of AsPC-1 pancreatic cancer cells and sensitizes them to TRAIL-induced apoptosis. Investig. New Drugs 2011, 29, 777-785.

181. Atmaca, H.; Bozkurt, E.; Uzunoglu, S.; Uslu, R.; Karaca, B. A diverse induction of apoptosis by trabectedin in MCF-7 (HER2-/ER+) and MDA-MB-453 (HER2+/ER-) breast cancer cells. Toxicol. Lett. 2013, 221, 128-136.

182. Toume, K.; Tsukahara, K.; Ito, H.; Arai, M.A.; Ishibashi, M. Chromomycins A2 and A3 from marine actinomycetes with TRAIL resistance-overcoming and Wnt signal inhibitory activities. Mar. Drugs 2014, 12, 3466-3476.

183. Yoshida, T.; Maoka, T.; Das, S.K.; Kanazawa, K.; Horinaka, M.; Wakada, M.; Satomi, Y.; Nishino, H.; Sakai, T. Halocynthiaxanthin and peridinin sensitize colon cancer cell lines to tumor necrosis factor-related apoptosis-inducing ligand. Mol. Cancer Res. 2007, 5, 615-625.

184. Ganesan, P.; Noda, K.; Manabe, Y.; Ohkubo, T.; Tanaka, Y.; Maoka, T.; Sugawara, T.; Hirata, T. Siphonaxanthin, a marine carotenoid from green algae, effectively induces apoptosis in human leukemia (HL-60) cells. Biochim. Biophys. Acta 2011, 1810, 497-503.

185. Shin, D.Y.; Kim, G.Y.; Kim, N.D.; Jung, J.H.; Kim, S.K.; Kang, H.S.; Choi, Y.H. Induction of apoptosis by pectenotoxin-2 is mediated with the induction of DR4/DR5, Egr-1 and NAG-1, activation of caspases and modulation of the Bcl-2 family in p53-deficient Hep3B hepatocellular carcinoma cells. Oncol. Rep. 2008, 19, 517-526.

186. Hossain, Z.; Sugawara, T.; Hirata, T. Sphingoid bases from sea cucumber induce apoptosis in human hepatoma HepG2 cells through p-AKT and DR5. Oncol. Rep. 2013, 29, 1201-1207.

187. Gajate, C.; Mollinedo, F. Cytoskeleton-mediated death receptor and ligand concentration in lipid rafts forms apoptosis-promoting clusters in cancer chemotherapy. J. Biol. Chem. 2005, 280, 11641-11647.

188. Martinez-Serra, J.; Maffiotte, E.; Martin, J.; Bex, T.; Navarro-Palou, M.; Ros, T.; Plazas, J.M.; Vogler, O.; Gutierrez, A.; Amat, J.C.; et al. Yondelis(R) (ET-743, Trabectedin) sensitizes cancer cell lines to CD95-mediated cell death: New molecular insight into the mechanism of action. Eur. J. Pharmacol. 2011, 658, 57-64.

189. Tohme, R.; Darwiche, N.; Gali-Muhtasib, H. A journey under the sea: The quest for marine anti-cancer alkaloids. Molecules 2011, 16, 9665-9696. 
190. Demetri, G.D.; von Mehren, M.; Jones, R.L.; Hensley, M.L.; Schuetze, S.M.; Staddon, A.; Milhem, M.; Elias, A.; Ganjoo, K.; Tawbi, H.; et al. Efficacy and Safety of Trabectedin or Dacarbazine for Metastatic Liposarcoma or Leiomyosarcoma After Failure of Conventional Chemotherapy: Results of a Phase III Randomized Multicenter Clinical Trial. J. Clin. Oncol. 2015, doi:10.1200/JCO.2015.62.4734.

191. FDA Approves New Therapy for Certain Types of Advanced Soft Tissue Sarcoma. Available

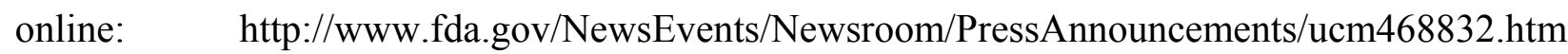
(accessed on 23 October 2015)

192. Wiley, S.R.; Schooley, K.; Smolak, P.J.; Din, W.S.; Huang, C.P.; Nicholl, J.K.; Sutherland, G.R.; Smith, T.D.; Rauch, C.; Smith, C.A. Identification and characterization of a new member of the TNF family that induces apoptosis. Immunity 1995, 3, 673-682.

(C) 2015 by the authors; licensee MDPI, Basel, Switzerland. This article is an open access article distributed under the terms and conditions of the Creative Commons Attribution license (http://creativecommons.org/licenses/by/4.0/). 